\title{
Taxonomic study on infraspecific taxa of Lespedeza maximowiczii and hybrids with related species
}

\author{
Dong-Pil JIN, Jong-Won PARK and Byoung-Hee CHOI*
}

Department of Biological Sciences, Inha University, Incheon 22212, Korea

(Received 12 November 2019; Revised 14 December 2019; Accepted 25 December 2019)

\begin{abstract}
Many infraspecific taxa within Lespedeza maximowiczii and hybrids with related species have been described, but taxonomic verification remains controversial. We examined the morphological traits of hybrids $(L$. chiisanensis and L. patentibicolor) and infraspecific taxa (var. tomentella, elongata, and tricolor) and analyzed their genetic structures using microsatellite loci. Flower and leaflet shapes in var. tomentella and elongata were within the range of variation of those in var. maximowiczii, and individuals in the two former varieties were grouped into var. maximowiczii. Lespedeza maximowiczii var. tricolor was similar to L. buergeri in terms of the structure and flower color, whereas the leaflet and bracteole shapes of var. tricolor were similar to those of var. maximowiczii. Based on the genetic structure $(K=3)$, var. tricolor had a mixed lineage with L. maximowiczii and L. buergeri. In addition, these formed a distinct lineage at $K=5$. For two hybrids, the flower and leaflet structure in L. chiisanensis did not differ from those in L. maximowiczii, whereas the flowers of $L$. patentibicolor were within the range of variation of $L$. bicolor. In addition, L. chiisanensis and L. patentibicolor were assigned to L. maximowiczii and L. bicolor, respectively, based on the genetic structure. We treated var. tomentella and elongata as a forma, f. friebeana, because L. friebeana preceded var. tomentella, whereas var. tricolor was treated as a distinct species, L. tricolor. Lespedeza chiisanensis was recognized as a synonym of L. maximowiczii. Lespedeza patentibicolor was considered to be $L$. bicolor.
\end{abstract}

Keywords: Hybrid, infraspecific taxa, Lespedeza maximowiczii, morphological variation, microsatellites, taxonomic treatment

The genus Lespedeza Michx., which belongs to the family Fabaceae, includes approximately 44 species and is disjunctively distributed in Asia and North America (Ohashi and Nemoto, 2014). Within this genus, two subgenera [Lespedeza and Macrolespedeza (Maxim.) H. Ohashi] were recently circumscribed based on the morphology of seedlings and molecular data (Ohashi and Nemoto, 2014). The former grows in the eastern region of North America, whereas the latter is distributed from East Asia to India. In the subgenus Macrolespedeza, the section Macrolespedeza is composed of subshrub and shrub that bears only chasmogamous flowers, whereas the section Junceae (Maxim.) H. Ohashi \& T. Nemoto is composed of herbs and subshrubs that bear both chasmogamous and cleistogamous flowers (Ohashi and Nemoto, 2014). The members of the section Macrolespedeza are morphologically varied (Lee, 1965; Akiyama, 1988), which hinders the identification of some species. Many hybrids in the taxa of this section have been reported based on morphological evidence (Lee, 1965; Akiyama, 1988, 2004). Previous molecular phylogenies showed the signal for hybridization within this section (Xu et al., 2012, 2017), i.e., most species are not supported as monophyletic according to their taxonomic status.

Thirteen Lespedeza species have been recognized in Korea and six belong to the section Macrolespedeza (Choi, 2007). In this study, we focused on L. maximowiczii C. K. Schneid., which is in the section. Until recently, this species was known to be distributed in China, Korea, and Tsushima Island of Japan (Ohashi et al., 2009). However, the Chinese plant was separated into L. pseudomaximowiczii D. P. Jin, B. Xu \& B.

*Author for correspondence: bhchoi@inha.ac.kr 
H. Choi because of its distinct morphology and genetic features (Jin et al., 2018); thus, it is accepted that $L$. maximowiczii grows in Korea and a narrow area of Tsushima Island. Like other Macrolespedeza species, many infraspecific taxa of L. maximowiczii have been recorded, including var. elongata Nakai, var. tomentella Nakai, var. tricolor Nakai, and f. albiflora Uyeki (Nakai, 1927; Uyeki, 1941). The taxonomic ranks of these taxa have been argued by different researchers (Hatusima, 1967; Akiyama, 1988). For example, Hatusima (1967) treated L. maximowiczii as a subspecies [= subsp. praecox (Nakai) Hatusima] of closely related species, L. buergeri Miq., var. tomentella, and var. tricolor were simultaneously changed to the forma $[=\mathrm{f}$. tomentella (Nakai) Hatusima] of subsp. praecox and other subspecies [= subsp. tricolor (Nakai) Hatusima], respectively. However, Akiyama (1988) treated var. tomentella as a synonym of L. maximowiczii. Furthermore, L. maximowiczii var. elongata and var. tricolor were thought to be synonyms of L. maximowiczii (Akiyama, 1988). Many hybrids related to L. maximowiczii have been recognized in Korea (Lee, 1965). In detail, the following hybrids were described: $L$. angustifolioides T. Lee (including L. maximowiczii var. elongata as its synonym) [L. maximowiczii $\times$ L. japonica $\mathrm{L}$. H. Bailey var. intermedia (Nakai) Nakai], L. chiisanensis T. Lee (L. maximowiczii $\times$ L. bicolor Trucz.), L. maritima Nakai (L. maximowiczii $\times$ L. cyrtobotrya Miq.), L. patentibicolor T. Lee (L. maximowiczii var. tomentella $\times$ L. bicolor), and L. patentielongata T. Lee (L. maximowiczii var. tomentella $\times$ L. japonica var. intermedia). In Lee's subsequent study, he regarded L. maximowiczii var. tomentella as a hybrid species, i.e., L. $\times$ tomentella $($ Lee, 1980) $[=$ L. $\times$ friebeana Schindl. in Lee and Lee (1975)], between L. maximowiczii and $L$. japonica var. intermedia [= L. thunbergii (DC.) Nakai subsp. thunbergii in Ohashi et al. (2009)]. Furthermore, two hybrids (L. angustifolioides and $L$. patentielongata) and $L$. maximowiczii var. elongata were circumscribed into $L . \times$ friebeana in that paper (Lee and Lee, 1975). In the case of L. patentibicolor, because one putative parent was treated as a hybrid (Lee and Lee, 1975), this species would be a hybrid between a species (L. maximowiczii) and a hybrid (L. $\times$ friebeana). Although Lee's studies improved our understanding of the Korean Lespedeza species (Lee, 1965; Lee and Lee, 1975), flowers have not been sufficiently examined despite their importance for identification (Akiyama, 1988). Genetic evidence regarding hybrids is also lacking. Therefore, resolving this complex taxonomic issue related to L. maximowiczii requires morphological and genetic analyses.
To verify hybridization, a putative hybrid needs to be examined by genetic evidence and morphological characters. Partial chloroplast DNA and nuclear ribosomal internal transcribed spacer (nrITS) data do not appropriately delimit the species (Xu et al., 2012, 2017), perhaps because of their frequent hybridization or incomplete lineage sorting. Thus, we applied microsatellite markers developed from $L$. maritima (Jin et al., 2016a) to these taxa. Microsatellite markers are codominant and highly polymorphic. Furthermore, they may cover multiple loci in the nuclear DNA (Duminil et al., 2012). Microsatellite markers show the hybridization and introgression between species, in genera such as Quercus L. (Lee et al., 2014; Castillo-Mendoza et al., 2019), Ulmus L. (Brunet et al., 2013), and Populus L. (Zeng et al., 2016). The genetic traits of $L$. pseudomaximowiczii were also revealed by the comparison with other Lespedeza species using microsatellite markers (Jin et al., 2018).

Here, our goals were to (1) examine the morphological characters of infraspecific taxa of L. maximowiczii and hybrids with related species, (2) investigate the genetic structure among taxa using microsatellite loci, and (3) discuss the taxonomic entities based on these results.

\section{Materials and Methods}

\section{Morphological examination and survey of geographical distribution}

To compare the morphological characters of typical $L$. maximowiczii with infraspecific taxa and hybrids, we collected specimens from the field sampling and deposited them in the Herbarium of Inha University (IUI). The sample information is detailed in Table 1. Additional morphological examination was conducted by observing specimens from the Korea National Arboretum (KH), College of Agriculture Life Sciences, Seoul National University (SNUA), Institute of Botany, Chinese Academy of Sciences (PE), and the Herbarium of University of Tokyo (TI). In particular, we observed T. B. Lee's collections to understand how he regarded hybrids in his previous studies (Lee, 1965), i.e., L. chiisanensis, L. patentibicolor, L. angustifolioides, and L. patentielongata (Fig. 1). Among these, the latter two were regarded as a hybrid of L. maximowiczii and L. thunbergii $[L . \times$ friebeana $(=L . \times$ tomentella)], including L. maximowiczii var. elongata (Lee and Lee, 1975). L. angustifolioides, L. patentielongata, and $L$. maximowiczii var. elongata were characterized by acuminate at both ends of the leaflet. The two formers were distinguished based only on the hairs on the inflorescence (appressed vs. 
Table 1. Sampling information for Lespedeza maximowiczii and its related species in Korea that were used in this study.

\begin{tabular}{|c|c|c|c|}
\hline Taxa & Population locality & Coordinates & $\begin{array}{c}\text { No. of } \\
\text { samples }\end{array}$ \\
\hline \multirow[t]{2}{*}{ Lespedeza maximowiczii f. maximowiczii (조록싸리) } & JR Jirisan Mt., Namwon, Jeonbuk, Korea & $35^{\circ} 17^{\prime} \mathrm{N}, 127^{\circ} 31^{\prime} \mathrm{E}$ & 8 \\
\hline & SD Deoksung Mt., Yesan, Chungnam, Korea & $36^{\circ} 40^{\prime} \mathrm{N}, 126^{\circ} 37^{\prime} \mathrm{E}$ & 8 \\
\hline \multirow{5}{*}{$\begin{array}{l}\text { L. maximowiczii var. tomentella (=f. friebeana) } \\
\text { (털조록싸리) }\end{array}$} & CC Cheomchalsan Mt., Uisin, Jindo, Jeonnam, Korea & $34^{\circ} 28^{\prime} \mathrm{N}, 126^{\circ} 19^{\prime} \mathrm{E}$ & 9 \\
\hline & DY Hyangsan 7-gil, Danyang, Chungbuk, Korea & $37^{\circ} 03^{\prime} \mathrm{N}, 128^{\circ} 26^{\prime} \mathrm{E}$ & 1 \\
\hline & JR Jirisan Mt., Namwon, Jeonbuk, Korea & $35^{\circ} 17^{\prime} \mathrm{N}, 127^{\circ} 31^{\prime} \mathrm{E}$ & 12 \\
\hline & SD Deoksungdsn Mt., Yesan, Chungnam, Korea & $36^{\circ} 40^{\prime} \mathrm{N}, 126^{\circ} 37^{\prime} \mathrm{E}$ & 8 \\
\hline & JS Jeoksangsan Mt., Muju, Cheonam, Korea & $35^{\circ} 56^{\prime} \mathrm{N}, 127^{\circ} 41^{\prime} \mathrm{E}$ & 22 \\
\hline \multirow[t]{2}{*}{ L. maximowiczii var. elongata (=f.friebeana) (늦싸리) } & JR Jirisan Mt., Namwon, Jeonbuk, Korea & $35^{\circ} 17^{\prime} \mathrm{N}, 127^{\circ} 31^{\prime} \mathrm{E}$ & 3 \\
\hline & JS Jeoksangsan Mt., Muju, Cheonam, Korea & $35^{\circ} 56^{\prime} \mathrm{N}, 127^{\circ} 41^{\prime} \mathrm{E}$ & 4 \\
\hline L. maximowiczii var. tricolor (= L. tricolor) (삼색싸리) & CC Cheomchalsan Mt., Uisin, Jindo, Jeonnam, Korea & $34^{\circ} 28^{\prime} \mathrm{N}, 126^{\circ} 19^{\prime} \mathrm{E}$ & 10 \\
\hline L.patentibicolor (진도싸리) & & & 12 \\
\hline $\begin{array}{l}\text { L. chiisanensis (= L. maximowiczii f. maximowiczii) } \\
\text { (지리산싸리) }\end{array}$ & JR Jirisan Mt., Namwon, Jeonbuk, Korea & $35^{\circ} 17^{\prime} \mathrm{N}, 127^{\circ} 31^{\prime} \mathrm{E}$ & 2 \\
\hline L. bicolor (싸리) & DY Hyangsan 7-gil, Danyang, Chungbuk, Korea & $37^{\circ} 03^{\prime} \mathrm{N}, 128^{\circ} 26^{\prime} \mathrm{E}$ & 7 \\
\hline \multirow[t]{2}{*}{ L. buergeri } & TB Taibaisan Mt., Lushi, Henan, China & $33^{\circ} 52^{\prime} \mathrm{N}, 111^{\circ} 19^{\prime} \mathrm{E}$ & 14 \\
\hline & O Kayagasan Mt., Hokuto, Yamanashi, Japan & $35^{\circ} 47^{\prime} \mathrm{N}, 138^{\circ} 30^{\prime} \mathrm{E}$ & 15 \\
\hline \multirow[t]{3}{*}{ L. thunbergii subsp. thunbergii (풀싸리) } & BS Jangsangbongsan Mt., Busan, Korea & $35^{\circ} 6^{\prime} \mathrm{N}, 129^{\circ} 6^{\prime} \mathrm{E}$ & 5 \\
\hline & CC Cheomchalsan Mt., Uisin, Jindo, Jeonnam, Korea & $34^{\circ} 28^{\prime} \mathrm{N}, 126^{\circ} 19^{\prime} \mathrm{E}$ & 8 \\
\hline & SD Deoksungsan Mt., Yesan, Chungnam, Korea & $36^{\circ} 40^{\prime} \mathrm{N}, 126^{\circ} 37^{\prime} \mathrm{E}$ & 3 \\
\hline
\end{tabular}

patent) (Lee, 1965). Thus, we considered them to be $L$. maximowiczii var. elongata. Additional specimen examination was conducted using the website of the Royal Botanical Garden Kew (K), Naturalis (L), and Global Biodiversity Information Facility (GBIF) dataset published by the T. B. Lee herbarium (Chang and Kim, 2019). We could not observe specimens of L. maximowiczii f. albiflora; therefore, this taxon was not included in this study. All observations of morphological characters were made with a stereomicroscope (Leica MZ8; Wetzlar, Germany), and floral features were measured following criteria that were stipulated by Akiyama (1988).

\section{Sampling, DNA extraction, and the microsatellite polymerase chain reaction (PCR)}

Leaves were sampled from the voucher specimens shown in Table 1 and preserved using silica gel. The dried leaves from Lespedeza species were used for genomic DNA extraction. We used an MG Plant Genomic DNA Extraction SV Miniprep Kit (MGmed, Seoul, Korea). Although we mostly followed the manufacturer's instructions, initial incubation and ice incubation times were extended to acquire sufficient DNA.
We used the following 11 microsatellite loci (Jin et al., 2016a): LMS3, LMS7, LMS11, LMS18, LMS28, LMS33, LMS39, LMS45, LMS47, LMS53, LMS55, LMS58, and LMS61. The PCR protocol utilized these markers with a GeneAmp PCR System 2700 Thermal Cycler (Applied Biosystems, Foster City, CA, USA). Each reaction mixture ( $10 \mu \mathrm{L}$ total volume) contained $5 \mathrm{ng}$ of DNA, plus $5 \mu \mathrm{L}$ of $2 \times$ Plus Mix (Dongsheng Biotech, Guangdong, China) that comprised $0.4 \mathrm{mM}$ dNTPs, $2 \times$ PCR buffer with $4 \mathrm{mM} \mathrm{MgSO}_{4}$, and $0.4 \mathrm{U} / \mu \mathrm{L}$ of Taq DNA polymerase. The mixtures also contained the appropriate $0.08 \mu \mathrm{M}$ forward M13 (-21)-tagged primer, a $0.3 \mu \mathrm{M}$ reverse primer, and a $0.3 \mu \mathrm{M}$ M13 (-21) labeled fluorescent marker (NED, PET, VIC, or 6-FAM). Conditions included initial denaturation at $94^{\circ} \mathrm{C}$ for $3 \mathrm{~min}, 30$ cycles at $94^{\circ} \mathrm{C}$ for $30 \mathrm{~s}, 53^{\circ} \mathrm{C}$ for $30 \mathrm{~s}$, and $72^{\circ} \mathrm{C}$ for $45 \mathrm{~s}$, without a final extension. Afterward, the PCR products were visualized on $2 \%$ agarose gels and resolved to genotype on an $\mathrm{ABI} 3730 \mathrm{XL}$ sequencer with GeneScan 500 LIZ size standards (Applied Biosystems). This fragment analysis was performed by Macrogen, Inc. (Seoul, Korea). The sizes of the alleles were manually determined using the program GENEMAPPER 3.7 (Applied Biosystems). 

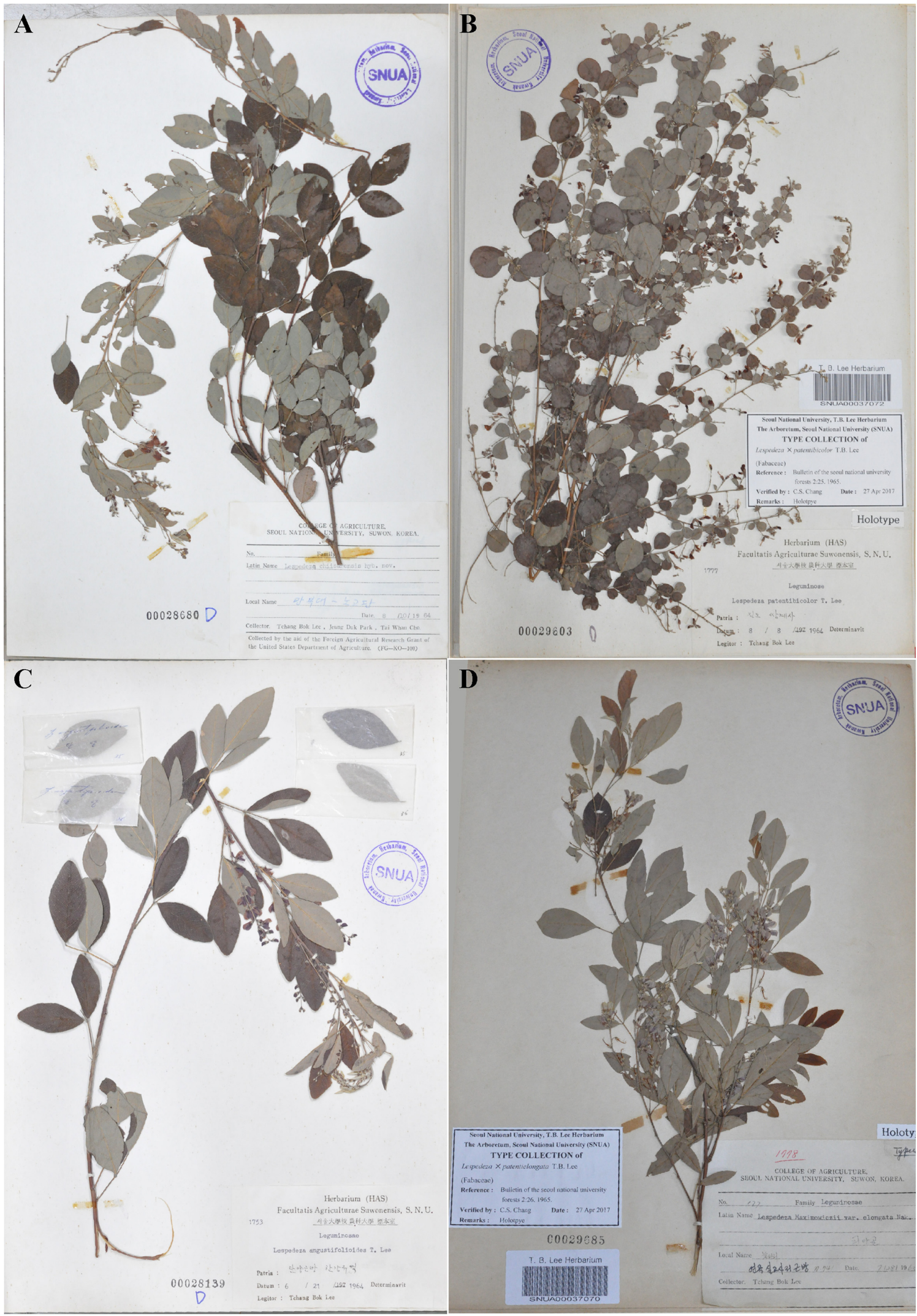

Fig. 1. Four Lespedeza hybrids that were investigated in this study. These were recognized by Lee $(1965,1980)$. A. L. chiisanensis (lectotype). B. L. patentibicolor (holotype). C. L. angustifolioides (lectotype). D. L. patentielongata (holotype). 


\section{Microsatellite data analyses}

The fragment sizes of all loci were genotyped according to the individual. To determine the assignment pattern of the six taxa, Bayesian clustering was conducted using our genotypic data. This analysis was performed with STRUCTURE 2.3.4 (Pritchard et al., 2000), selecting the admixture ancestry and correlated allele frequency models. Ten iterations were run for each cluster ( $K=1$ to 20 ), with 30,000 burn-ins followed by 300,000 Markov chain Monte Carlo repetitions. The optimum $K$ value was determined based on $\Delta K$ according to the number of clusters, which was estimated using STRUCTURE HARVESTER (Earl and von Holdt, 2012). The results from each run were generated to a representative stacked bar chart using the Clustering Markov Packager Across K (CLUMPAK) on the web (Kopelman et al., 2015) to summarize and generate representative pie charts associated with each $K$ value. To represent the relationship among species, we reconstructed the neighbor-joining (NJ) tree based on Nei's genetic distances $\left(D_{\mathrm{A}}\right)$ (Nei et al., 1983). $D_{\mathrm{A}}$ between individuals was calculated with the POPULATIONS 1.2.32 (Langella, 2011).

\section{Results}

\section{Morphological examination on infraspecific taxa of $L$. maximowiczii and hybrids with related species}

We compared morphological characters to reconsider the taxonomic position of taxa related to L. maximowiczii. The measured values of the infraspecific taxa and hybrids are shown in Tables 2 and 3, respectively.

The results for the infraspecific taxa (Fig. 2, Table 2) showed that L. maximowiczii var. tomentella $(8.9-[10.1]-11.2 \mathrm{~mm})$ had slightly longer flowers than those of var. elongata (9.0-[9.6]$10.2 \mathrm{~mm}$ ) and var. maximowiczii (8.2-[9.5]-10.9 mm). Flowers of var. tricolor $(8.4-[9.0]-9.5 \mathrm{~mm})$ were slightly shorter than those of var. maximowiczii, which were similar to those of $L$. buergeri $(8.2-[9.0]-9.7 \mathrm{~mm})$. The color of standard petals (purple) was almost identical among the infraspecific taxa, whereas var. tricolor had a pale-yellow standard petal with purple dots inside, which was similar to that of L. buergeri. The order of the length of petals [K (keel petal) $\fallingdotseq \mathrm{S}$ (standard petal) $>\mathrm{W}$ (wing petal)] was the same in var. maximowiczii

Table 2. Comparison of morphological traits of Lespedeza maximowiczii and its infraspecific taxa.

\begin{tabular}{|c|c|c|c|c|c|}
\hline & $\begin{array}{l}\text { L. maximowiczii var. } \\
\text { maximowiczii }\end{array}$ & $\begin{array}{l}\text { var. tomentella } \\
(=\mathrm{f} . \text { friebeana })\end{array}$ & $\begin{array}{l}\text { var. elongata } \\
(=\mathrm{f} . \text { friebeana })\end{array}$ & $\begin{array}{l}\text { var. tricolor } \\
(=\text { L. tricolor })\end{array}$ & L. buergeri \\
\hline Hair on inflorescence & \multicolumn{3}{|c|}{ Adpressed to patent hair Adpressed to patent hair Adpressed to patent hair } & Adpressed hair & Adpressed hair \\
\hline Length of flower (mm) & $8.2-(9.5)-10.9$ & $8.9-(10.1)-11.2$ & $9.0-(9.6)-10.2$ & $8.4-(9.0)-9.5$ & $8.2-(9.0)-9.7$ \\
\hline Color of standard petal & $\begin{array}{l}\text { Purple with denser } \\
\text { purple dot inside }\end{array}$ & $\begin{array}{l}\text { Purple with denser } \\
\text { purple dot inside }\end{array}$ & $\begin{array}{l}\text { Purple with denser } \\
\text { purple dot inside }\end{array}$ & $\begin{array}{l}\text { Pale yellow with } \\
\text { purple dot inside }\end{array}$ & $\begin{array}{l}\text { Pale yellow with } \\
\text { purple dot inside }\end{array}$ \\
\hline Length of standard petal (mm) & $7.0-(8.5)-10.0$ & $8.2-(9.3)-10.4$ & $8.0-(8.9)-9.6$ & $6.7-(7.6)-8.6$ & $6.8-(7.6)-8.4$ \\
\hline Length of standard petal claw (mm) & $0.7-(1.1)-1.5$ & $0.8-(1.2)-1.5$ & $0.8-(1.1)-1.4$ & $1.0-(1.2)-1.7$ & $0.8-(1.0)-1.2$ \\
\hline Length of wing petal (mm) & $6.4-(7.5)-9.2$ & $7.1-(8.6)-9.9$ & 7.4-(8.3)-9.0 & $6.5-(7.4)-8.3$ & $6.1-(7.6)-8.8$ \\
\hline Length of wing petal claw (mm) & $1.7-(2.4)-2.9$ & $1.6-(2.4)-2.9$ & $2.1-(2.5)-2.9$ & $2.0-(2.5)-2.9$ & $1.7-(2.2)-2.9$ \\
\hline Length of wing petal lamina (mm) & $4.5-(5.4)-6.7$ & $4.8-(6.3)-7.3$ & $5.0-(6.0)-6.8$ & $4.5-(5.0)-5.6$ & $4.6-(5.5)-5.6$ \\
\hline Length of keel petal (mm) & $7.8-(8.8)-9.8$ & $8.8-(9.5)-10.7$ & $8.2-(9.0)-9.7$ & $8.3-(8.7)-9.0$ & $8.0-(8.7)-9.5$ \\
\hline Length of keel petal claw (mm) & $2.0-(2.6)-3.3$ & $2.4-(2.8)-3.3$ & $2.3-(2.6)-2.8$ & $2.1-(2.6)-2.9$ & $2.1-(2.4)-2.7$ \\
\hline Length of keel petal lamina (mm) & $5.6-(6.3)-7.0$ & $6.2-(6.9)-7.5$ & $6.1-(6.6)-7.0$ & $5.4-(6.1)-6.4$ & $5.9-(6.3)-6.8$ \\
\hline Length of calyx tube (mm) & $1.2-(1.5)-2.1$ & $1.4-(1.8)-2.2$ & $1.2-(1.4)-1.6$ & $1.3-(1.5)-1.6$ & $1.3-(1.6)-2.1$ \\
\hline Length of calyx lobe (mm) & $1.5-(2.3)-3.5$ & $1.8-(3.1)-4.1$ & $2.5-(3.0)-3.2$ & $0.7-(0.9)-1.1$ & $0.6-(0.9)-1.1$ \\
\hline Length of bracteoles (mm) & $0.5-(1.1)-2.1$ & $0.4-(1.0)-1.9$ & $1.2-(1.5)-1.8$ & $0.8-(1.1)-1.4$ & $1.3-(1.6)-1.8$ \\
\hline Width of bracteoles (mm) & $0.2-(0.5)-1.0$ & $0.2-(0.4)-0.6$ & $0.3-(0.4)-0.6$ & $0.6-(0.7)-0.8$ & $0.6-(1.0)-1.3$ \\
\hline Shape of leaflets at apex & $\begin{array}{l}\text { Mostly acute to } \\
\text { acuminate }\end{array}$ & $\begin{array}{l}\text { Mostly acute to } \\
\text { acuminate }\end{array}$ & Acuminate & $\begin{array}{l}\text { Mostly acute to } \\
\text { acuminate }\end{array}$ & Acute to obtuse \\
\hline $\begin{array}{l}\text { Density of hairs on upper surface of } \\
\text { leaflet (number per } 4 \mathrm{~mm}^{2} \text { ) }\end{array}$ & $1-(8)-59$ & $38-(51)-90$ & $27-(54)-80$ & $0-(0)-1$ & $0-(0)-1$ \\
\hline
\end{tabular}

Note: The number in parenthesis indicates mean value. 


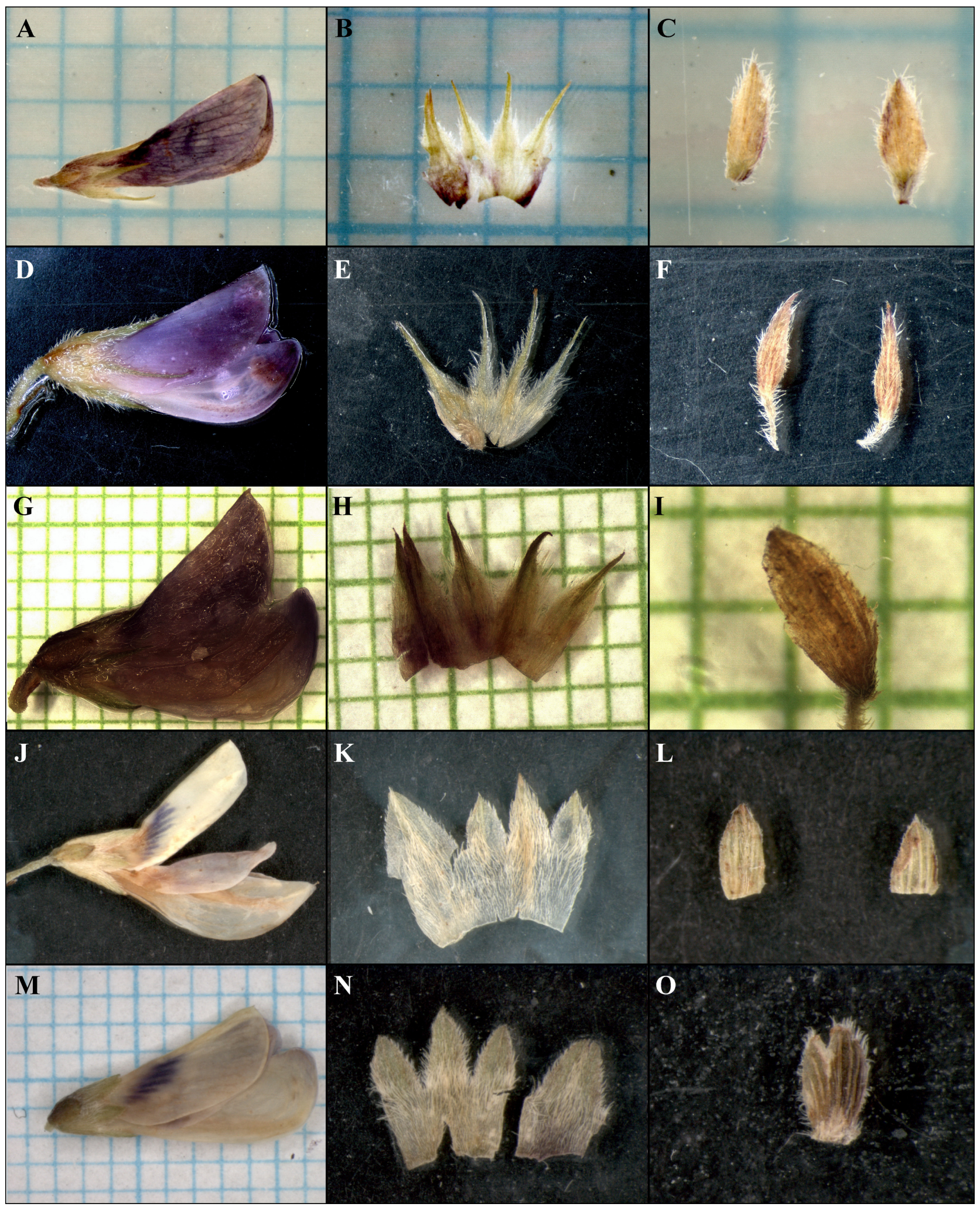

Fig. 2. Comparison of floral characters of Lespedeza maximowiczii (including infraspecific taxa) and L. buergeri. A-C. L. maximowiczii var. maximowiczii (= f. maximowiczii). D-F. var. tomentella (= f. friebeana). G-I. var. elongata (= f. friebeana). J-L. var. tricolor $(=$ L. tricolor). M-O. L. buergeri. A, D, G, J, M. flower. B, E, H, K, N. calyx. C, F, I, L, O bracteole. 
(S, mean $8.5 \mathrm{~mm}$; W, mean $7.5 \mathrm{~mm}$; $\mathrm{K}$, mean $8.8 \mathrm{~mm}$ ), var. tomentella $(\mathrm{S}$, mean $9.3 \mathrm{~mm}$; W, mean $8.6 \mathrm{~mm}$; K, mean $9.5 \mathrm{~mm}$ ), and var. elongata $(\mathrm{S}$, mean $8.9 \mathrm{~mm}$; W, mean $8.3 \mathrm{~mm}$; K, mean $9.0 \mathrm{~mm}$ ). L. maximowiczii var. tricolor presented a different order $(\mathrm{K}>\mathrm{W} \fallingdotseq \mathrm{S})$, and this order was also observed in L. buergeri. Calyx lobes were longer than the calyx tube in var. maximowiczii (lobe, 1.2-[1.5]-2.1 mm; tube, 1.5-[2.3]-3.5 mm). L. maximowiczii var. tomentella and var. elongata also harbored longer calyx lobes (var. tomentella, 1.8-[3.1]-4.1 mm; var. elongata, 2.5-[3.0]$3.2 \mathrm{~mm}$ ) than calyx tubes (var. tomentella, $1.4-[1.8]-2.2 \mathrm{~mm}$; var. elongata, 1.2-[1.4]-1.6 mm). However, L. maximowiczii var. tricolor had shorter calyx lobes than calyx tubes (lobe, $0.7-[0.9]-1.1 \mathrm{~mm}$; tube, 1.3-[1.5]-1.6 mm). The shape of the calyx lobes at the apex was acuminate for var. maximowiczii, var. tomentella, and var. elongata, whereas that of var. tricolor was acute, similar to that of L. buergeri. In all taxa, the ratio of claw to lamina in the wing and keel petals was 1:2-2.9. In the case of bracteoles, the infraspecific taxa of $L$. maximowiczii, except for var. tricolor, were ovate to elliptic; thus, the length was generally approximately two times longer than the width. Bracteoles of var. tricolor were also ovate, but the narrow form was not observed (width vs. length $\fallingdotseq$ 1:1.7). Bracteoles of the Chinese L. buergeri generally were normal to broadly ovate, whereas those of Japanese individuals were almost round. Their ratio of width to length was similar to that of L. maximowiczii var. tricolor. Regarding hairs, the upper surface of the leaflets of L. maximowiczii was almost glabrous (1-[8]-59 per $4 \mathrm{~mm}^{2}$ ), whereas var. tomentella had more appressed hairs on the surface of leaflets (38-[51]-90 per $4 \mathrm{~mm}^{2}$ ). L. maximowiczii var. elongata also showed a similar density as the former two (27-[54]-80 per $4 \mathrm{~mm}^{2}$ ), whereas L. maximowiczii var. tricolor harbored almost glabrous and light green colored leaflets, similar to those of L. buergeri.

Regarding the hybrids, L. chiisanensis and L. maximowiczii showed similar flower structures. Flowers of L. patentibicolor and L. bicolor were also similar in shape (Fig. 3, Table 3). For standard petal, L. maximowiczii and L. chiisanensis had a distinct claw, whereas L. patentibicolor and L. bicolor had no obvious claw, which gradually decreased from the middle to bottom (Fig. 3). Wing petals of L. maximowiczii (6.4-[7.5]$9.2 \mathrm{~mm}$ ) and L. chiisanensis (7.4-[8.3]-9.0 mm) were shorter than their keel petals (L. maximowiczii, 7.8-[8.8]-9.8 mm; $L$. chiisanensis, 8.8-[9.5]-10.7 mm). Although L. bicolor had longer keel petals $(8.6-[10.1]-11.2 \mathrm{~mm})$ than wing petals (8.6[9.5]-11.0 mm), the difference in their length (mean $0.6 \mathrm{~mm}$ ) was smaller than that of L. maximowiczii (mean $1.3 \mathrm{~mm}$ ) and L. chiisanensis (mean $1.2 \mathrm{~mm}$ ). In the case of L. patentibicolor, wing petals (7.1-[8.3]-8.9 mm) were longer than the keel petals (6.4-[7.6]-8.5 mm). For the ratio of claw to lamina in wing and keel petals, L. maximowiczii and L. chiisanensis had lamina

Table 3. Comparison of morphological traits of typical Lespedeza maximowiczii and hybrids with related species.

\begin{tabular}{|c|c|c|c|c|}
\hline & L. maximowiczii & L. chiisanensis & L. patentibicolor & L. bicolor \\
\hline Length of flower (mm) & $8.2-(9.5)-10.9$ & $10.2-(11.1)-12.0$ & $8.1-(9.4)-11.5$ & $10.5-(11.7)-12.7$ \\
\hline Length of standard petal (mm) & $7.0-(8.5)-10.0$ & $9.6-(10.0)-10.3$ & $8.9-(9.2)-9.8$ & $10.2-(11.3)-12.1$ \\
\hline Length of standard petal claw (mm) & $0.7-(1.1)-1.5$ & $1.2-(1.5)-1.7$ & $1.8-(2.0)-2.1$ & $1.8-(2.0)-2.4$ \\
\hline Width of standard petal (mm) & $4.4-(5.6)-6.8$ & $5.2-(5.8)-6.4$ & $5.5-(5.6)-5.8$ & $6.0-(7.7)-10.2$ \\
\hline Claw of standard & Distinct & Distinct & No distinct & No distinct \\
\hline Length of wing petal (mm) & $6.4-(7.5)-9.2$ & $7.4-(8.3)-9.0$ & $7.1-(8.3)-8.9$ & $8.6-(9.5)-11.0$ \\
\hline Length of wing petal claw (mm) & $1.7-(2.4)-2.9$ & $2.4-(2.6)-3.0$ & $2.5-(3.1)-3.8$ & $3.2-(3.5)-3.7$ \\
\hline Length of wing petal lamina (mm) & $4.5-(5.4)-6.7$ & $4.8-(5.8)-6.2$ & $4.8-(5.3)-5.9$ & $5.5-(6.1)-7.2$ \\
\hline Length of keel petal (mm) & $7.8-(8.8)-9.8$ & $8.9-(10.3)-11.1$ & $6.4-(7.6)-8.5$ & $8.6-(10.1)-11.2$ \\
\hline Length of keel petal claw (mm) & $2.0-(2.6)-3.3$ & $2.6-(2.9)-3.2$ & $2.9-(3.3)-3.8$ & $3.3-(3.7)-4.2$ \\
\hline Length of keel petal lamina (mm) & $5.6-(6.3)-7.0$ & $6.5-(7.5)-8.1$ & $3.7-(4.5)-5.7$ & $6.5-(6.8)-7.2$ \\
\hline Length of calyx tube (mm) & $1.2-(1.5)-2.1$ & $0.7-(2.1)-2.9$ & $2.0-(2.3)-2.8$ & $2.0-(2.2)-2.3$ \\
\hline Length of calyx lobe (mm) & $1.5-(2.3)-3.5$ & $1.1-(2.1)-2.9$ & $0.9-(1.2)-1.7$ & $1.0-(1.4)-1.8$ \\
\hline Shape of calyx lobe at apex & Mostly acuminate & Mostly acuminate & \multicolumn{2}{|c|}{ Mostly obtuse to round Mostly obtuse to round } \\
\hline Shape of leaflets at apex & $\begin{array}{l}\text { Mostly acute to } \\
\text { acuminate }\end{array}$ & Acute to obtuse & Obtuse to emarginate & Obtuse to emarginate \\
\hline
\end{tabular}

Note: The number in parenthesis indicates mean value. 


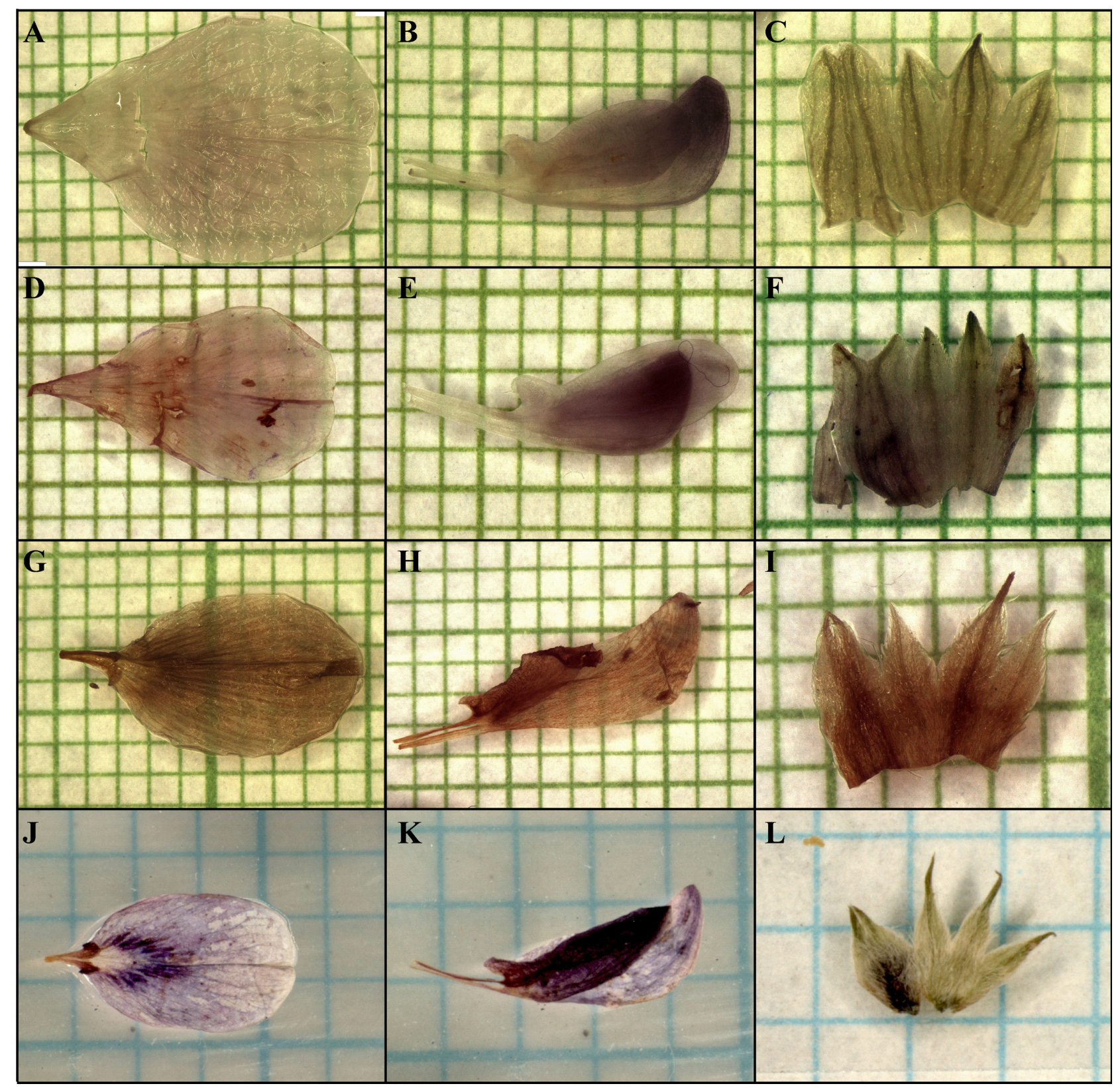

Fig. 3. Comparison of floral characters among hybrids suggested by Lee $(1965,1980)$ and parents. A-C. L. bicolor. D-F. L. patentibicolor. G-I. L. chiisanensis (= f. maximowiczii). J-L. L. maximowiczii. A, D, G, J. Standard petal. B, E, H, K. Ratio of length (wing petal vs. keel petal). C, F, I, L. Calyx.

that was approximately two times longer than the claw, but the lamina of L. bicolor and L. patentibicolor were not much longer than the claw. Calyx lobes diverged below the middle of the calyx in L. maximowiczii and L. chiisanensis, whereas the lobes of L. bicolor and L. patentibicolor did not. The shapes of the calyx lobes at their apex were also considerably different: acuminate to acute in L. maximowiczii and L. chiisanensis and obtuse to round in L. bicolor and L. patentibicolor.

\section{Genotypic analyses of Macrolespedeza taxa concerning $L$. maximowiczii}

Regarding the Bayesian clustering results performed by STRUCTURE, the optimum cluster number was determined to be three because the highest $\Delta K$ was at this value (Fig. 4). At $K=3$ (Fig. 5), most of L. bicolor, L. patentibicolor, and $L$. thunbergii subsp. thunbergii were assigned to the same lineage (orange). The infraspecific taxa of $L$. 
maximowiczii (except for var. tricolor) and L. chiisanensis were assigned into the same lineage (light blue). Most of L. buergeri were grouped into a distinct lineage (dark purple), although some individuals appeared to be closer to L. maximowiczii. In the case of L. maximowiczii var tricolor, all individuals appeared to have mixed genetic features from other infraspecific taxa (var. maximowiczii, var. tomentella, and var. elongata) and L. buergeri. Since $K=5$ (Fig. 5), L. maximowiczii var. tricolor was assigned to an independent lineage (purple).

The NJ tree was almost consisted of the Bayesian

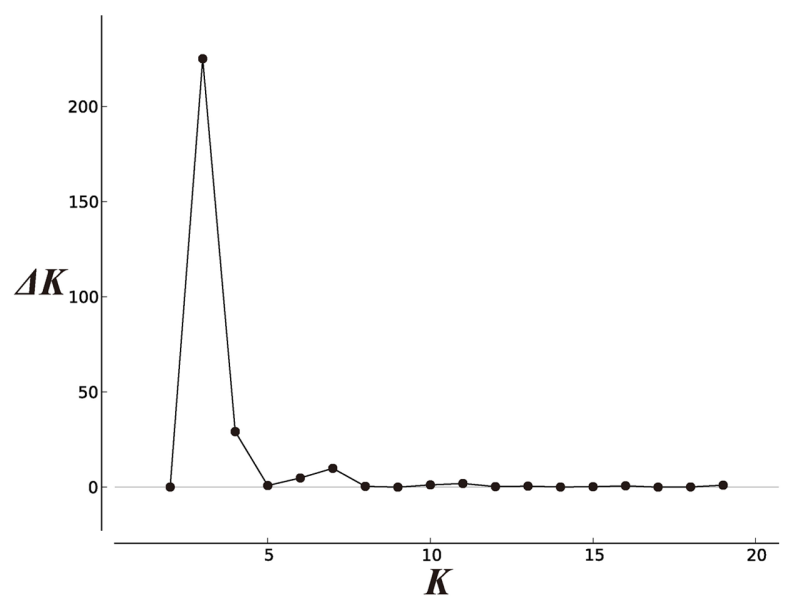

Fig. 4. $\Delta K$ statistics versus the number of clusters $(K)$ calculated based on Bayesian clustering analysis using STRUCTURE. clustering results (Fig. 6), despite this tree was weakly supported by low bootstrap value. Within clade A, $L$. thunbergii, L. bicolor, and L. patentibicolor were mainly clustered. The individuals of $L$. buergeri were included within clade B and C. In case of L. chiisanensis, this taxon was clustered with infraspecific taxa of L. maximowiczii (clade $\mathrm{F}$ and $\mathrm{H}$ ).

\section{Discussion}

\section{Taxonomic reconsideration of infraspecific taxa of L. maximowiczii}

We examined the morphological traits of L. maximowiczii and its infraspecific taxa and analyzed their relationships using 11 microsatellite markers. Although morphological differences among L. maximowiczii var. maximowiczii, var. tomentella, and var. elongata were observed, the variation ranges mostly overlapped (Table 2). The width of leaflets showed a gradual change from narrow (represented as var. elongata) to wide (represented as var. maximowiczii). According to Nakai (1927), var. elongata is characterized by oblong or oblong-lanceolate leaflets that are acuminate at both ends. This leaflet form is also observed regardless of the presence of hair on the upper surface. $L$. maximowiczii var. tomentella bears hairs on the upper surface of leaflets, whereas the upper surface of the leaflet of var. maximowiczii becomes glabrous (Lee, 1965; Akiyama, 1988). Patent hair on inflorescences and branches

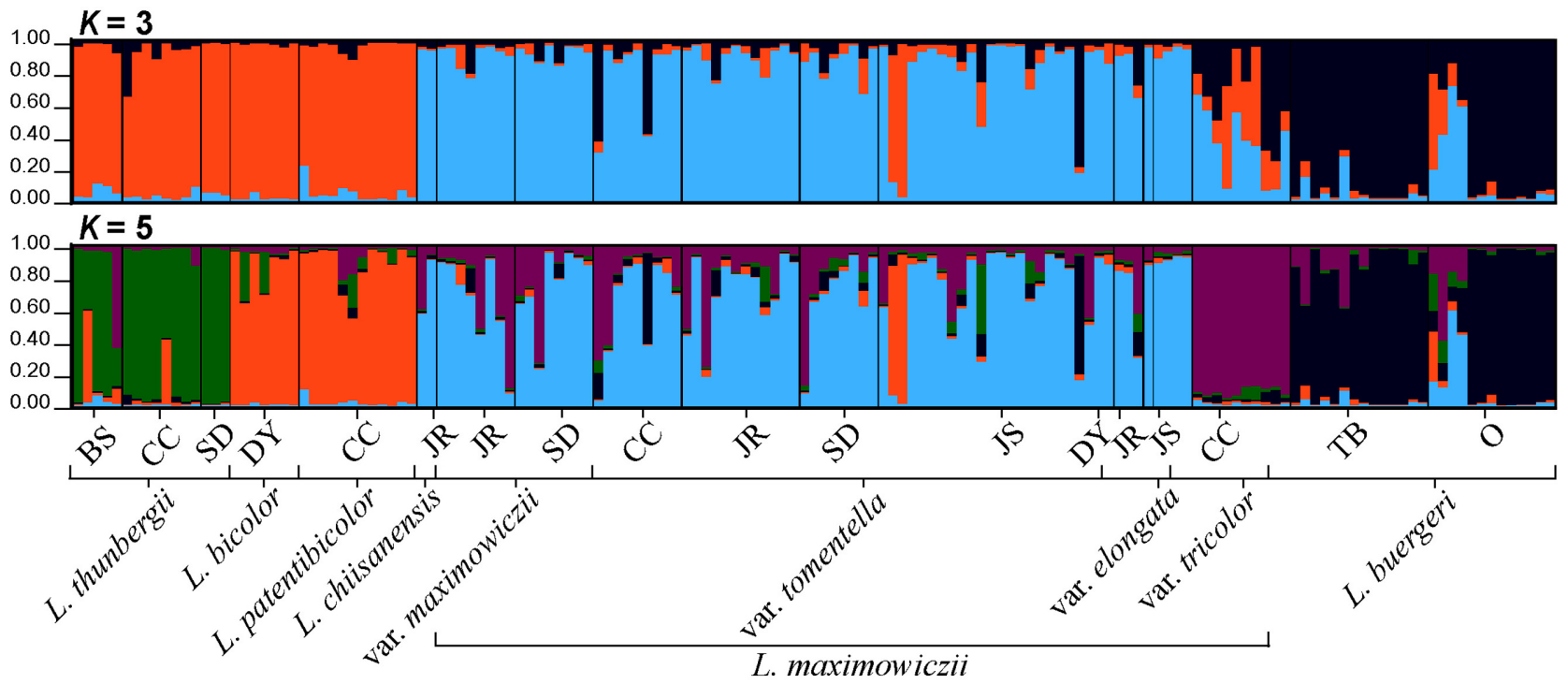

Fig. 5. Results of Bayesian clustering for Lespedeza maximowiczii and other Lespedeza species. This analysis was conducted based on 11 microsatellite loci. Lineage assignments are the probability of individuals at $K=3$, and 5. Population codes along the x-axis are identical to those in Table 1, after code of species name. Numbers along the $y$-axis indicate posterior probability of belonging to the cluster. 


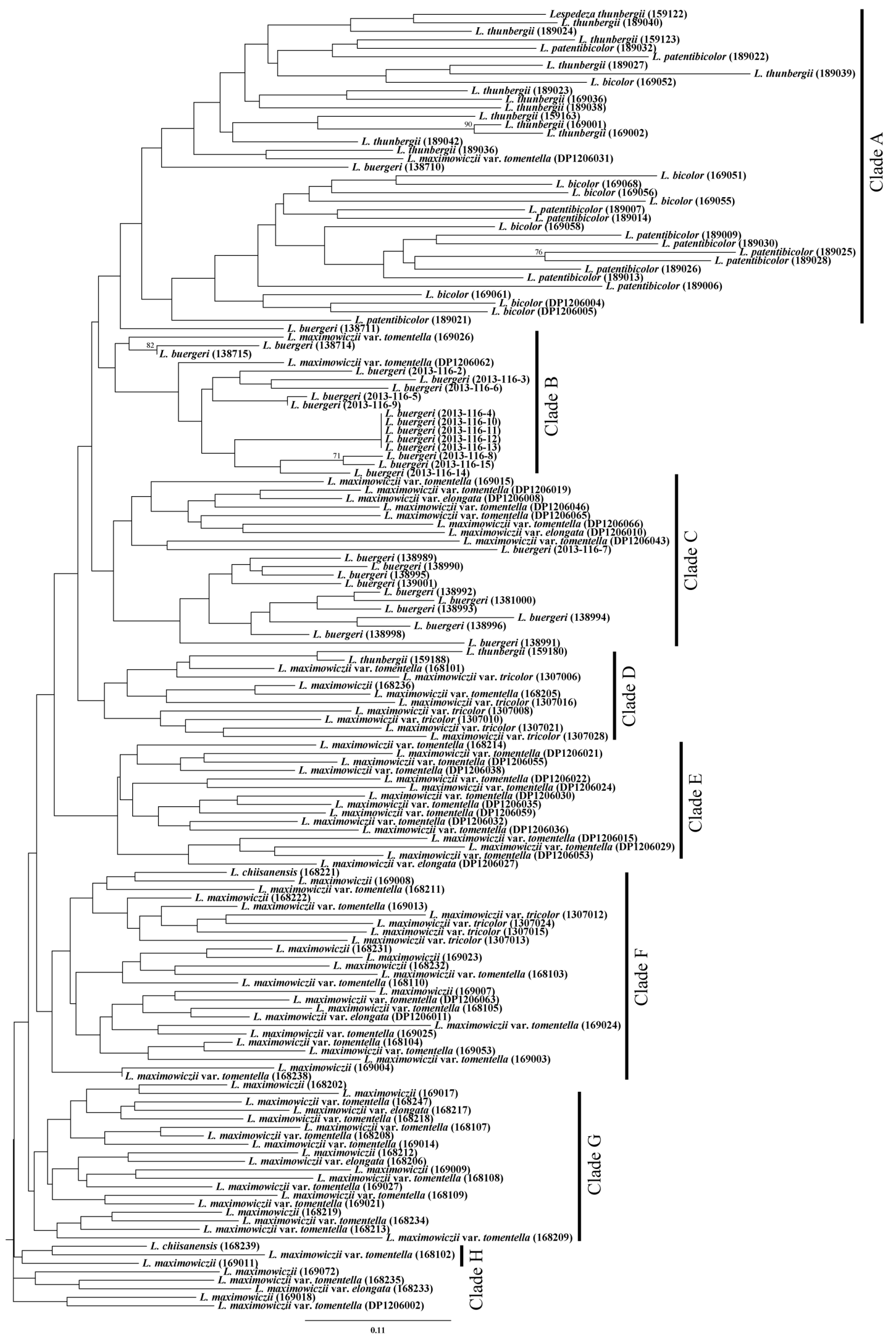

Fig. 6. Neighbor-joining phylogenetic tree of the infraspecific taxa of Lespedeza maximowiczii and related species based on microsatellite loci. The number above branch indicate bootstrap value $(>50 \%)$. Voucher numbers are given in parentheses. 
of var. tomentella has been suggested to be a specific trait (Lee and Lee, 1975) and this taxon has even been inferred to be a hybrid between $L$. maximowiczii and $L$. thunbergii (Lee and Lee, 1975). When we examined the specimens (ca. 1,100) that are deposited in $\mathrm{KH}$ to determine this hypothesis, patent hairs on inflorescences and branches were observed regardless of the pubescent on the upper surface of the leaflets. Appressed hairs on inflorescences were even observed in individuals bearing pubescent leaflets. Thus, we concluded that these two morphological traits were not correlated. In the Bayesian clustering results (Fig. 5), nearly all individuals of L. maximowiczii var. tomentella shared the same genetic lineage as $L$. maximowiczii var. maximowiczii; however, var. tomentella did not share a genetic lineage with $L$. thunbergii. Thus, L. maximowiczii var. tomentella could not be considered a hybrid, as suggested by Lee and Lee (1975). This result of the genetic analysis also applied to L. maximowiczii var. elongata (Fig. 5). As previously mentioned, $L$. maximowiczii var. elongata has been treated as a synonym for L. $\times$ friebeana [= L. $\times$ tomentella in Lee (1980)] (Lee and Lee, 1975), including L. angustifolioides and $L$. patentielongata that were described as new hybrids in Lee (1965). We determined that $L$. angustifolioides and $L$. patentielongata were also not hybrids. However, $L$. maximowiczii var. tomentella was not morphologically different from var. maximowiczii, except for the hair on the upper surface of the leaflets (Fig. 2, Table 2). The pubescent form (var. tomentella) often grows with the glabrous form (var. maximowiczii) in the same place. Considering its resemblance with var. maximowiczii in both morphology and geographic distribution, var. tomentella should be ranked at the level of forma. However, the species epithet was changed because $L$. friebeana preceded L. oldhamii var. tomentella Nakai (= L. maximowiczii var. tomentella) (Lee and Lee, 1975). Both taxa were observed to bear villous leaflets. Therefore, we named the forma $L$. maximowiczii f. friebeana (Schindl.) D. P. Jin, J. W. Park \& B. H. Choi.

However, L. maximowiczii var. tricolor is different from other infraspecific taxa in morphology. Its pale-yellow standard and keel petals appeared to be closer to L. buergeri. In the original description of this taxon (Nakai, 1923), the color of the keel petals was mentioned as rosy, but it is white or pale yellow in both field and herbarium specimens. In the order of the length of petals, L. maximowiczii var. tricolor $(\mathrm{K}>\mathrm{W} \fallingdotseq \mathrm{S})$ resembles that of $L$. buergeri $(\mathrm{K}>\mathrm{W} \fallingdotseq \mathrm{S})$ and some individuals even showed longer wing petals than standard petals (Table 2). Although length of wing and standard petals were similar in some individuals of $L$. maximowiczii, no individuals were observed to bear wing petals longer than the standard petals. Calyx lobes at the apex for var. tricolor (acute) were within the variation of $L$. buergeri (acute to obtuse). However, bracteoles of var. tricolor appeared close to those of var. maximowiczii because these taxa do not have the round shape that is regarded as the synapomorphy of L. buergeri (Akiyama, 1988; Jin et al., 2016b). Taking into account the intermediate features of var. tricolor and the migration history, we suggest that $L$. maximowiczii var. tricolor originated from an ancient hybridization between L. buergeri and L. maximowiczii (Jin et al., 2016b). Genotypes of var. tricolor were of mixed lineage of var. maximowiczii and L. buergeri $(K=3)$ (Fig. 5). In addition, most individuals of var. tricolor were determined to have a lineage that was distinguished from var. maximowiczii and L. buergeri from $K=5$, which was supported by the low $\Delta K$ (Figs. 4,5 ). Therefore, we treated L. maximowiczii var. tricolor as a distinct species, L. tricolor (Nakai) D. P. Jin, J. W. Park \& B. H. Choi.

\section{Taxonomic reconsideration of hybrids between $L$. maximowiczii and its related taxa}

Hybrids between L. maximowiczii and its related taxa were analyzed based on morphological and genetic traits. Although both L. patentibicolor (L. maximowiczii var. tomentella $\times L$. bicolor) and L. chiisanensis (L. maximowiczii $\times$ L. bicolor) are related to L. bicolor (Lee, 1965, 1980), their external appearance varies greatly (Figs. 1, 3). The flower of $L$. patentibicolor was within the morphological variation of $L$. bicolor. In detail, the length of claws and lamina of wing and keel petals of $L$. patentibicolor were approximately equal, and standard petals had no distinct claw, as does L. bicolor (Akiyama, 1988). In particular, Lee $(1965,1980)$ described the calyx lobes of $L$. patentibicolor as an intermediate form between its putative parents. However, our observations were opposed to what Lee $(1965,1980)$ suggested. The inflorescence of L. bicolor is generally glabrous (Lee, 1965, 1980; Akiyama, 1988), whereas that of L. patentibicolor is covered with hairs (Lee, 1965, 1980). The morphotype of L. patentibicolor could be considered L. bicolor var. sericea Nakai (Nakai, 1927), which has been treated as a synonym or forma of L. bicolor by other researchers (Hatusima, 1967; Akiyama, 1988). L. patentibicolor could be also be regarded as L. melanantha Nakai, characterized by semicircular calyx lobes at the apex and wing petals longer than keel petals (Nakai, 1927; Akiyama, 1988). Although the shape of the calyx is different in both 
taxa, the order of the petals in length is the same for both (Lee, 1978). In the case of L. melanantha, the width of the calyx lobes is longer than their length (Akiyama, 1988); however, morphological variation must be examined. In Bayesian clustering analysis (Fig. 5), most of L. patentibicolor were assigned to the same lineage as L. bicolor, but they did not share a genetic lineage with L. maximowiczii var. tomentella. On the NJ tree (Fig. 6), L. patentibicolor was clustered into a clade with L. bicolor and L. thunbergii, supporting the result of the Bayesian clustering analysis. Although the discussion regarding the relationship among infraspecific taxa of $L$. bicolor and taxonomic delimitation of L. melanantha is limited in this study, based on our data, we believe that $L$. patentibicolor is circumscribed into L. bicolor.

L. chiisanensis has acute to obtuse leaflets (or emarginate) at the apex and acuminate calyx lobes (Lee, 1965). Its inflorescence is thin, similar to that of L. bicolor (Lee, 1965). However, L. chiisanensis bears appressed hair, similar to that of L. maximowiczii (Lee, 1965). However, these characters were not well separated from L. maximowiczii. Although the inflorescence of some specimens was thin in the upper part, the lower part was not different from that of the common $L$. maximowiczii. The corolla of $L$. chiisanensis resembled that of L. maximowiczii rather than L. bicolor (Fig. 3, Table 3). Standard petal of L. chiisanensis showed definite claw and auricular shapes that were similar to those of L. maximowiczii. Acuminate calyx lobes appeared to be typical of $L$. maximowiczii. Additionally, the wing and keel petals were in the form of L. maximowiczii, i.e., the lamina was two times longer than the claw. In Bayesian clustering analysis (Fig. 5), the individuals, identified as L. chiisanensis, were grouped into L. maximowiczii. Hence, both morphological and genetic traits suggested that $L$. chiisanensis was within the variation of $L$. maximowiczii. When considering these facts, it is likely that this hybrid should be treated as a synonym of L. maximowiczii.

\section{A key to Lespedeza maximowiczii and its related taxa}

1. Standard and keel petal purple, standard longer than wing petal in length; calyx lobe acuminate and elongated at apex; leaflets glabrous or pubescent on upper surface, usually green to dark green. $\cdots$ Lespedeza maximowiczii

1. Standard and keel petal pale yellow to white, standard slightly longer or the same as wing petal in length; calyx lobe acute to obtuse and not elongated at apex; leaflets glabrous on upper surface, usually green to light green.

2. Bracteoles ovate to orbicular; leaflet apex usually acute to acuminate. L. tricolor
2. Bracteoles elliptic to ovate; leaflet apex usually obtuse to acute. ……………………………….. L. buergeri

\section{Taxonomic Treatment}

Lespedeza maximowiczii C. K. Schneid., Ill. Handb. Laubholz. 2: 113, f. 70-71, 1907.-TYPE: Korea. Gangwondo: Wonsan-si, Aug 1901, Faurie 51 (holotype, A, seen as photo!).

L. buergeri Miq. var. praecox Nakai, Bot. Mag. Tokyo 25: 55, 1911; L. praecox (Nakai) Nakai ex Koidz., Bot. Mag. Tokyo 39: 24, 1925; L. buergeri Miq. subsp. praecox (Nakai) Hatus., Mem. Fac. Agr. Kagoshima Univ. 6: 6, 1967.

L. densiflora Uyeki, Bull. Nat. Hist. Soc. Corea 20: 17, 1935.

L. chiisanensis T. Lee, Bull. Seoul Nat. Univ. For. no. 2: 11, 1965. syn. nov.-TYPE: Korea. Jeollanam-do: Guryegun, Jirisan Mt., from Manbokdae to Nogodan, 10 Aug 1964, T. Lee et al. s.n. (lectotype, designated here, SNUA, see Fig. 1A).

\section{A key to the forma of Lespedeza maximowiczii}

1. Leaflet upper surface pubescent during fruiting season, sparsely hairy during flowering season.

f. maximowiczii

1. Leaflet upper surface glabrous during fruiting season, densely hairy during flowering season. $\cdots \cdots . .$. f. friebeana

\section{f. maximowiczii}

Korean name: Jo-rok-ssa-ri (조록싸리).

Shrub, erect, up to $2.5 \mathrm{~m}$ tall, much branched at upper part. Bark brown to grayish-brown, clefted when old. Branches terete, glabrous, reddish brown to brown, stretched slightly in zigzag pattern; young branches with appressed or patent hairs. Stipules linear triangular to linear, brown, 2-3 mm long. Leaves (based on upper branches) trifoliate, petiolate, stipulate, usually larger at lower part of plant; petioles 9-25 mm long, with sparse to dense appressed to patent hairs; rachises 5.5-15.5 mm long, with sparse to dense appressed or patent hairs; terminal leaflets green to dark green, petioloulate; petiolules ca. $2 \mathrm{~mm}$ long, swollen, appressed to patent hair; lamina $3-6 \mathrm{~cm}$ long, $1-4 \mathrm{~cm}$ wide, elliptic to broad ovate, entire, acute to acuminate (to obtuse) at apex, rounded or obtuse (to acuminate) at base, upper surface with sparsely appressed hairs during flowering season, becoming glabrous during fruiting, lower surface with more densely appressed hairs; lateral leaflets slightly smaller than terminal. Inflorescence axillary pseudo-raceme, usually one (rarely two or three) per leaf, similar length with subtending leaf, 3-7 cm long, 12-18 (to 32) flowered, with appressed to 
patent hair. Flowers 8-11 mm long, purple to reddish purple. Bracteoles at base of calyx, ovate to oblong-ovate, pubescent, ca. $1 \mathrm{~mm}$ long. Calyx $2.7-6.3 \mathrm{~mm}$ long, campanulate, pubescent, four-lobed below middle part; lobes subequal in length, acuminate at apex, usually elongated; lower lobe longest in length; lateral ones ovate, 1.5-3.5 mm long, shortest in length; upper one broad ovate with two clefts at middle part. Standard petal similar with keel petal in length, longer than wing petal; standard petal 7.0-10.5 mm long, 4.4-6.9 mm wide, with auricles, purple to reddish purple; lamina elliptic to obovate, slightly emarginate at apex, deep purple dot inside, paler outside; auricle well developed; claw $0.7-1.5 \mathrm{~mm}$ long; wing petal $6.4-9.9 \mathrm{~mm}$ long, $1.3-2.7 \mathrm{~mm}$ wide, auriculate, deep or reddish purple; lamina oblong or elliptic, 4.5-7.3 mm long, deep or reddish purple, with auricle at base; claw 1.6$2.9 \mathrm{~mm}$ long, white; keel petal 7.5-10.7 mm long, 2.2-3.7 mm wide; lamina slightly falcate, reddish or light purple, 5.6$7.5 \mathrm{~mm}$ long; claw 2.0-3.3 mm long, white. Stamens 10, similar to keel petal in length, diadelphous $(9+1)$, white; filaments equal length; anthers elliptic, retuse at both sides, ca. $0.4 \mathrm{~mm}$ long, ca. $0.2 \mathrm{~mm}$ width, yellow. Pistil same length as stamen, with appressed hairs from base to middle; style elongated above anthers; ovary narrow elliptic during flowering season, hairy. Legume slightly distorted elliptic, compressed, stalked, subsessile, ca. $13 \mathrm{~mm}$ long, ca. $5 \mathrm{~mm}$ wide, pilose, elongated spine-tip. Seed reniform, ca. $5 \mathrm{~mm}$ long, ca. $3 \mathrm{~mm}$ wide, glabrous.

Flowering: (May-) June-July (-August).

Fruiting: September-October.

Distribution: Korea (all provinces), and Japan (north area of Tsushima Isl.).

Taxonomic note: Lespedeza maximowiczii (sect. Heterolespedeza Nakai) is distinguished by buds (flatted and alternatively arranged scales) from sect. Macrolespedeza Maxim. sens. str. (Ohashi et al., 2009). This species is woodier than other sect. Macrolespedeza species. Sometimes $L$. thunbergii subsp. thunbergii is erroneously identified as $L$. maximowiczii because of its acute leaflet apex and acuminate calyx lobe, but flower length is usually longer in the former (ca. $13 \mathrm{~mm}$ ) than the latter (ca. $10 \mathrm{~mm}$ ). L. buergeri resembles L. maximowiczii in bud and arrangement of leaves, but differs in the petals (pale yellow), and in length of petal ( $\mathrm{K}>\mathrm{S} \fallingdotseq$ W). In 1942, L. maximowiczii f. albiflora was recorded based on a specimen collected from Nangok (North Korea, Gangwondo) by Uyeki. This form was characterized by a white corolla. However, herbarium specimens identified as this forma in $\mathrm{KH}$ and SNUA are L. tricolor or L. maximowiczii. We observed no individual which bore a white corolla in the field.
Representative specimens examined: KOREA. Busan-si: Nam-gu, Igidae, 4 Sep 2015, D. P. Jin \& W. B. Cho 159169, 159176 (IUI). Chungcheongbuk-do: Danyang-gun, Sobaeksan Mt., 28 Jun 2016, D. P. Jin DP166309-166312 (IUI). Chungcheongnam-do: Yesan-gun, Deoksungsan Mt., 9 Sep 2016, D. P. Jin DP169004, DP16007, DP169017 (IUI). Gangwon-do: Jeongseon-gun, Buk-myeon, Nochusan Mt., 27 Jun 2007, J. O. Hyun et al. NAPI-0205 (KH); Hwacheon-gun, Gwangdoegsan Mt., 21 Jun 2004, E. H. Jung \& H. K. Moon K0721-057 (KH); Wonju-si, Chiaksan Mt., 27 Jun 2016, D. P. Jin DP166201, DP166204, DP166216 (IUI). Gyeonggi-do: Anyang-si, Manan-gu, Surisan Mt., 4 Jul 2007, S. C. Ko et al. HNHM-A-0788 (KH); Gapyeong-gun, Buk-myeon, Myoungjisan Mt., 20 Jun 2012, W. K. Paik PWK-2013-291 (KH); Dongducheon-si, Sangbongam-dong, Soyosan Mt., 20 Jul 2012, W. K. Paik PWK-2013-097 (KH); Namyangjusi, Hwado-eup, Cheonmasan Mt., 20 Jun 2016, D. P. Jin DP166101-166140 (IUI); Paju-si, Yeongjang-ri, Temple Bogwangsa, 31 May 1998, Y. M. Lee \& D. H Kim S-1349 (KH); Pocheon-si, Jikdong-ri, Korean national arboretum, S. H. Park ParkSH51431 (KH). Gyeongsangbuk-do: Yeongju-si, Murya-myeon, Seondalsan Mt., 8 Jul 2006, $B$. $O$. Oh et al. CBU-070571 (KH). Gyeongsangnam-do: Geoje-si, Gaemyeong-ri, 24 Jul 2013, D. C. Son \& B. K. Park HNHM-S-130288 (KH); Geoje-si, Mangsan Mt., 3 Sep 2015, D. P. Jin \& W. B. Cho 159033, 159036, 159040, 159066 (IUI); Miryang-si, Danjang-myeon, way to Temple Pyochungsa, 30 May 2007, H. J. Choi et al. ChoiHJ 70121 (KH); Namhae-gun, Samdong-myeon, Nogu, 18 Oct 2007, H. J. Choi et al. ChoiHJ 70465 (KH); Namhae-gun, Gamabong Mt., 20 Jun 2015, D. P. Jin DP156001, DP156009, DP156013 (IUI); Sancheong-gun, Jungsan-ri, Jirisan Mt., 21 Jul 2012, H. J. Choi 120721-hjchoi023 (KH); Sancheong-gun, Samjang-myeon, Wangdeungjae wetland, 30 Jun 2004, J. M. Jeong 04060222 (KH). Jeollabuk-do: Namwon-si, Deokdong-ri, 10 Oct 2004, C. Y. Yoon s.n. (KH); Jinan-gun, Jinan-eup, Jinan technical high school to Temple Gorimsa, 14 Oct 2005, Y. M Lee \& G. H. Nam LYM \& NGH 50279 (KH); Namwon-si, Jirisan Mt., Manbokdae, 14 Aug 2016 D. P. Jin DP168206, DP168217, DP168233 (IUI). Jeollanam-do: Boseong-gun, Hoechun-myeon, Illimsan Mt., 30 Aug 2019, D. P. Jin 198429 (IUI); Haenamgun, Seoheung-ri, Dalmasan Mt., 8 Aug 2005, H. J. Choi CHJ 50140 (KH); Jangheung-gun, Anyang-myeon, Jangjaedo Isl., 5 Jul 2006, Y. H. Cho et al. WR-060705-058 (KH). Seoul-si: Dobong-gu, Dobongsan Mt., 6 Jun 2005, S. H. Park Park SH51399 (KH); Achasan Mt., Seongdonggu, 23 Jul 2006, E. S. Jeon ESJeon60915 (KH). 
f. friebeana (Schindl.) D. P. Jin, J. W. Park \& B. H. Choi, comb. \& stat. nov.; L. friebeana Schindl., Repert. Sp. Nov. Regni Veg. 9: 514, 1911; T. Lee et M. Lee, Seoul Natl. Univ. Fac. Pap. Vol. 4: 3, 1975, pro parte (as L. $\times$ friebeana).TYPE: KOREA. Busan-si: 1859, C. Wilford s.n. (holotype, K, seen as photo!).

L. buergeri var. typica Nakai, Chosen Shokubutsu I: 260, 1914.

L. oldhamii Miq. var. tomentella Nakai, Bot. Mag. Tokyo 33: 203, 1919; L. maximowiczii C. K. Schneid. var. tomentella (Nakai) Nakai, Lesp. Jap. Korea, 39, 1927; L. buergeri Miq. subsp. praecox (Nakai) Hatus. f. tomentella (Nakai) Hatus., Mem. Fac. Agr. Kagoshima Univ. 6: 6, 1967.-TYPE: KOREA. Jeollanam-do: Wando-gun, 20 Jun 1913, Nakai 592 (lectotype of $L$. oldhamii Miq. var. tomentella Nakai, TI, seen as photo!).

L. maximowiczii C.K. Schneid. var. elongata Nakai, Lesp. Jap. Korea: 40, 1927.-TYPE: KOREA. Gyeongsangnam-do: Deoksan, Aug 1912, T. Mori 183 (holotype, TI, seen as photo!).

L. angustifolioides T. B. Lee, Bull. Seoul Nat. Univ. For. no. 2: 3, 1965. pro parte, quoad specim. Tanyang (= Danyanggun), Jecheun (= Jecheon-gun), Yeunkok (= Yeongok, Jirisan Mt., Gurye-gun).-TYPE: KOREA. Chungcheongbuk-do: Danyang-gun, 21 Jun 1964, T. Lee s.n. (lectotype, designed here, SNUA, see Fig. 1C).

L. patentielongata T. B. Lee, Bull. Seoul Nat. Univ. For. no. 2: 26, 1965. excl. specim. Temple Soodeuk (= Temple Sudeoksa, Yesan-gun).-TYPE: KOREA. Jeollanam-do: Gurye-gun, Pia valley, around Yeongok, 23 Jul 1963, T. Lee s.n. (holotype, SNUA!; isotype, SNUA!, see Fig. 1D).

Korean name: Teol-jo-rok-ssa-ri (털조록싸리).

This form bears adpressed hairs on the surface of leaflets until the fruiting period.

Taxonomic note: During the flowering period, this taxon is hardly distinguished from f. maximowiczii because the latter could also bear appressed hair on the upper surface of leaflets during that time. However, the upper surface of leaflets in $\mathrm{f}$. friebeana is generally more pubescent than f. maximowiczii ( $>51$ hairs per $2 \mathrm{~mm}^{2}$ ) (Table 2). Except for hairs on upper surface of leaflets, the morphological characters of $\mathrm{f}$. friebeana are included in the variation of f. maximowiczii. Lee mentioned that patent hair on the inflorescence is an important key to identify this taxon when considering Schindler's description (Lee 1965; Lee and Lee 1975). The patent hair on the inflorescence is usually observed in f. friebeana, but this character is sometimes observed in $\mathrm{f}$. maximowiczii. Therefore, caution is required, when this forma is identified based on this character.

This form has been known as tomentella since Nakai named it as L. oldhamii Miq. var. tomentella Nakai (Nakai, 1919). Although he mentioned L. tomentella Nakai based on the hairs of leaflets in his previous study (1914), he stopped publishing L. tomentella. This was because he knew L. friebeana before the publication of L. tomentella (Nakai, 1914). Lespedeza friebeana was described based on Wilford's collection (Schindler, 1911), which bears sparse hairs on the upper surface of leaflets. The hairs of the form are not different from those of L. maximowiczii var. tomentella (including L. oldhamii var. tomentella) (Nakai, 1919, 1927), and this was written in the original description. In addition, L. friebeana (Schindler, 1911) predate L. oldhamii var. tomentella (Nakai, 1919). The history of the species epithet was according to Lee and Lee (1975). Hence, we chose f. friebeana as the epithet of the form that bears sparse hairs on the upper surface of leaflets.

Representative specimens examined: KOREA. Chungcheongbuk-do: Danyang-gun, Daegang-myeon, Sobaeksan Mt., Jungnyeong $\rightarrow$ Yeonhwabong 1, 28 Jun 2016, D. P. Jin DP166314, DP166317, DP166320 (IUI); Jincheon-gun, Baekgok-myeon, Yangbaek-ri, Baetiseongji, 5 Oct 2008, S. H. Park \& J. C. Yang ParkSH83007 (KH); Yeongdong-gun, Sangchon-myeon, Minjujisan Mt., Temple Hwangnyongsa $\rightarrow$ top, 8 Sep 2009, Y. J. Chung \& J. C. Ahn SGU 1549 (KH). Chungcheongnam-do: Cheongyang-gun, Daechi-myeon, Janggok 1 bridge, 29 Aug 2009, E. S. Jeon ESJeon90896 (KH); Geumsan-gun, Nami-myeon, Baegamsan Mt., Nami Natural Recreation Forest $\rightarrow$ Peak Sunyabong, 24 Aug 2008, H. S. Lee HNU2243 (KH); Gongju-si, Banpo-myeon, Oncheon-ri, Gapasan Mt., 4 Oct 2008, J. I. Jeon \& H. S. Lee JEON12618 (KH); Nonsan-si, Sangwol-myeon, Yanghwa-ri, Gyeryongsan Mt., Temple Sinwon $\rightarrow$ Peak Yeoncheonbong, 2 Sep 2008, $H$. S. Lee HNU2315 (KH); Yesan-gun, Deoksungsan Mt., 9 Sep 2016, D.P. Jin DP169013-166315 (IUI). Gangwon-do: Donghae-si, Samhwa-dong, 9 Oct 2011, K. S. Lee et al. 534 (KH); Gangneung-si, Yeongok-myeon, Samsan-ri, Odaesan Mt., 5 Jul 1989, B. H. Choi IUI 18284 (KH); Hwacheon-gun, Yonghwasan Mt., 26 Sep 2010, B. O. Oh 100926-002 (KH); Jeongseon-gun, Yeoryang-myeon, Goyangsan Mt., 25 Jun 2010, J. H. Choi et al. K0601018 (KH); Pyeongchang-gun, Yongpyeong-myeon, Gyebangsan Mt., 4 Jul 2000, B. H. Choi et al. IUI 37168 (KH); Yeongwol-gun, Sangdong-eup, Naedeok-ri, Jangsan Mt., 13 Oct 2010, J. C. Yang et al. C101474 (KH); Wonju-si, Chiaksan Mt., 27 Jun 2016, D. P. Jin DP166220-166225 (IUI). Gyeonggi-do: Pocheonsi, Idongmyeon, Yeongbuk-ri, Baegunsan Mt., 1 Jul 2008, D. H. Lee Lee-80701012 (KH). Gyeongsangbuk-do: Cheongsong-gun, 
Andeok-myeon, Mungeo-ri, 20 Jun 2010, H. T. Shin et al. 1450-1453 (KH); Gyeongju-si, Danseoksan Mt., 10 Oct 2006, S. C. Go s.n. (KH); Bonghwa-gun, Chunyang-myeon, Guryongsan Mt., 28 Jun 2008, J. O. Hyun et al., 801028, 803010 (KH); Uljin-gun, Tonggosan Mt., 27 Aug 2014, D. P. Jin DP1408801, DP1408805, DP1408814, DP1408827, DP1408829 (IUI); Yeongcheon-si, Hwasan Mt., 3 Jun 2006, C. Y. Yoon Yoon $555(\mathrm{KH})$; Yeongdeok-gun, Byeonggokmyeon, Chilbosan Mt., Temple Yugeumsa, 10 Jun 2006, G. Y. Jeong Jeong $558(\mathrm{KH})$. Gyeongsangnam-do: Goseong-gun, Hail-myeon, Jwaisan Mt., 12 Sep 2009, K. H. Tae 2009-0754 (KH); Changnyeong-gun, Changnyeong-eup, Hwawangsan Mt., 17 Aug, 2009, S. C. Ko S. C. Ko 908040 (KH); Haman-gun, Yeohang-myeon, Yeohangsan Mt., 26 Sep 2009, J. I. Jeon JEON13147 (KH); Hapcheon-gun, Gayasan Mt., Baegundae, 15 Jun 2010, D. H. Lee D. H. Lee106334 (KH); Miryang-si, Danjang-myeon, Jaeyaksan Mt., 10 Oct 2009, S. C. Ko S. C. Ko 910031 (KH); Yangsan-si, Cheonseongsan Mt., Hwaeomneup swamp, 21 Aug 2008, S. H. Park \& J. C. Yang ParkSH81176 (KH). Gwangju-si: Eodeungsan Mt., Seobong-dong, Gwangsan-gu, 12 Oct 2010, D. O. Lim \& E. K. Che Kar LIM2610 (KH). Incheon-si: Michuhol-gu, Munhaksan Mt., 13 Jul 2016, J.S. Park \& J.W. Park 167001-167002 (IUI); Ongjin-gun, Deokjeokdo Isl., Guksubongsan Mt., 13 Jul 2010, J. H. Lee \& I. S. Choi J. H. Lee 107107 (KH). Jeollabuk-do: Namwon-si, Jirisan Mt., Manbokdae, 14 Aug 2016 D. P. Jin DP168221, DP168239 (IUI); Muju-gun, Jeoksangsan Mt., 22 Jun 2012, D. P. Jin DP1206015， DP1206019， DP1206046， DP1206047, DP1206065, DP1206008, DP1206011, DP1206016, DP1206020, DP1206042 (IUI); Jangsu-gun, Jangsu-eup, Deoksan-ri, Jangansan Mt., 19 Jul 2008, J. I. Jeon et al. JEON12372 (KH); Jangsu-gun, Jangsu-eup, Palgongsan Mt., 28 Aug 2008, H. I. Lim \& H. K. Kim LHI499 (KH); Jinangun, Jinan-eup, Gunsang-ri, Bugwisan Mt., 6 Sep 2019, D. P. Jin 199004, 199016, 199021 (IUI); Wanju-gun, Unju-myeon, Sanbuk-ri, Cheondeungsan Mt., 3 Oct 2008, H. I. Lim LHI1734 (KH). Jeollanam-do: Boseong-gun, Nodong-myeon, Hakdongri, near Yeje tunnel, 9 Sep 2009, Y. H. Cho et al. WR-090909024 (KH); Hwasun-gun, Dongbok-myeon, Yucheon-ri, Yucheonjeosuji, 23 Sep 2009, Y. H. Cho et al. WR-090909025 (KH); Jangseong-gun, Bugi-myeon, Ibamsan Mt., 30 May 2008, K. H. Kim IUI 46679 (KH); Jindo-gun, Cheomchalsan Mt., 12 Aug 2016, D. P. Jin DP168101 (IUI); Muan-gun, Seungdalsan Mt., 29 Aug 2019, D. P Jin 198401 (IUI); Mokposi, Dal-dong, Dallido Isl., 16 Sep 2010, Y. H. Cho et al. Y101233 (KH); Sinan-gun, Songgong-ri, Aphaedo Isl., Songgongsan Mt., 17 Jun 2010, Y. H. Cho et al. Y100430 (KH); Suncheon-si, Songgwang-myeon, Sinheung-ri, Jogyesan Mt.,
24 Jun 2009, Y. H. Cho et al. WR-090624-020 (KH). JAPAN. Nagasaki Pref.: Tsushima Isl., Waniura, 25 Jul 2012, J. Y. Lee \& I. S. Choi TS003 (IUI).

L. tricolor (Nakai) D. P. Jin, J. W. Park \& B. H. Choi, stat. nov. (Fig. 7); L. oldhamii Miq. var. tricolor Nakai, Bot. Mag. Tokyo 37: 78, 1923; L. maximowiczii Schneid. var. tricolor (Nakai) Nakai, Lesp. Jap. Korea: 40, 1927; L. buergeri Miq. subsp. tricolor (Nakai) Hatus., Mem. Fac. Agr. Kagoshima Univ. 6: 6, 1967.-TYPE: KOREA. Jeollanam-do: Wandogun, 20 Jun 1913, Nakai 600 (lectotype, TI, seen as photo!; isolectotype, TI, seen as photo!).

Korean name: Sam-saek-ssa-ri (삼색싸리).

Shrub, erect, 1-2 m tall, much branched at the upper part. Bark light brown to gray, vertically clefted when old. Branch terete, glabrous, light brown to brown, sometimes stretched in a zigzag pattern; young branches with appressed hairs. Stipules linear triangular to linear, brown, 2-3 $\mathrm{mm}$ long. Leaves trifoliate, petiolate, stipulate, usually bigger at lower part of plant; petioles 9-30 mm long, with appressed hairs; rachises 9-20 mm long, similar to petioles; terminal leaflets green, petiolulate; petiolules ca. $2 \mathrm{~mm}$ long, swollen, with densely appressed hair; lamina 3-7 cm long, 2-4 cm wide, elliptic to ovate, entire, acute to acuminate (to obtuse) at apex, rounded or obtuse (to acute) at base, upper surface glabrous, lower surface pubescent; lateral leaflets similar to terminal ones but relatively smaller in size. Inflorescence axillary pseudo-raceme, usually one (rarely two or three) per leaf, $2.6-8 \mathrm{~cm}$ long, similar or longer than subtending leaf, 18-38 flowered, with appressed to somewhat patent hairs. Bracts ovate to narrowly triangular, ca. $1 \mathrm{~mm}$ long. Flowers 8.4-9.6 mm long, pale yellow and purple mixed; pedicel 1-2 mm long, with appressed to somewhat patent hairs. Bracteoles at base of calyx, ovate to elliptic, pubescent at outside, ca. $1 \mathrm{~mm}$ long. Calyx 2.1-2.7 mm long, campanulate, pubescent, four-lobed until middle part; lobes subequal in length, similar to tube in length, acute at apex (not elongated like L. maximowiczii); lateral ones ovate, shortest in length, $0.7-1.1 \mathrm{~mm}$ long; upper ones broad ovate, slightly two-clefted. Keel petal longest among petals in length, standard longer or equal to wing; standard $6.7-8.6 \mathrm{~mm}$ long, $3.9-5.1 \mathrm{~mm}$ wide, with auricles; lamina oblong to obovate, slightly emarginate at apex, purple or reddish purple dot inside, pale yellow outside; auricle well developed, pale yellow; claw $1.0-1.7 \mathrm{~mm}$ long, pale yellow; wing petal $6.5-8.3 \mathrm{~mm}$ long, $1.6-1.8 \mathrm{~mm}$ wide, auriculate, purple and reddish purple at base; lamina oblong to elliptic, $4.8-5.6 \mathrm{~mm}$ long, auricle at base; claw 2.5-2.8 mm long; keel petal 8.3-9.0 mm long, 2.1- 


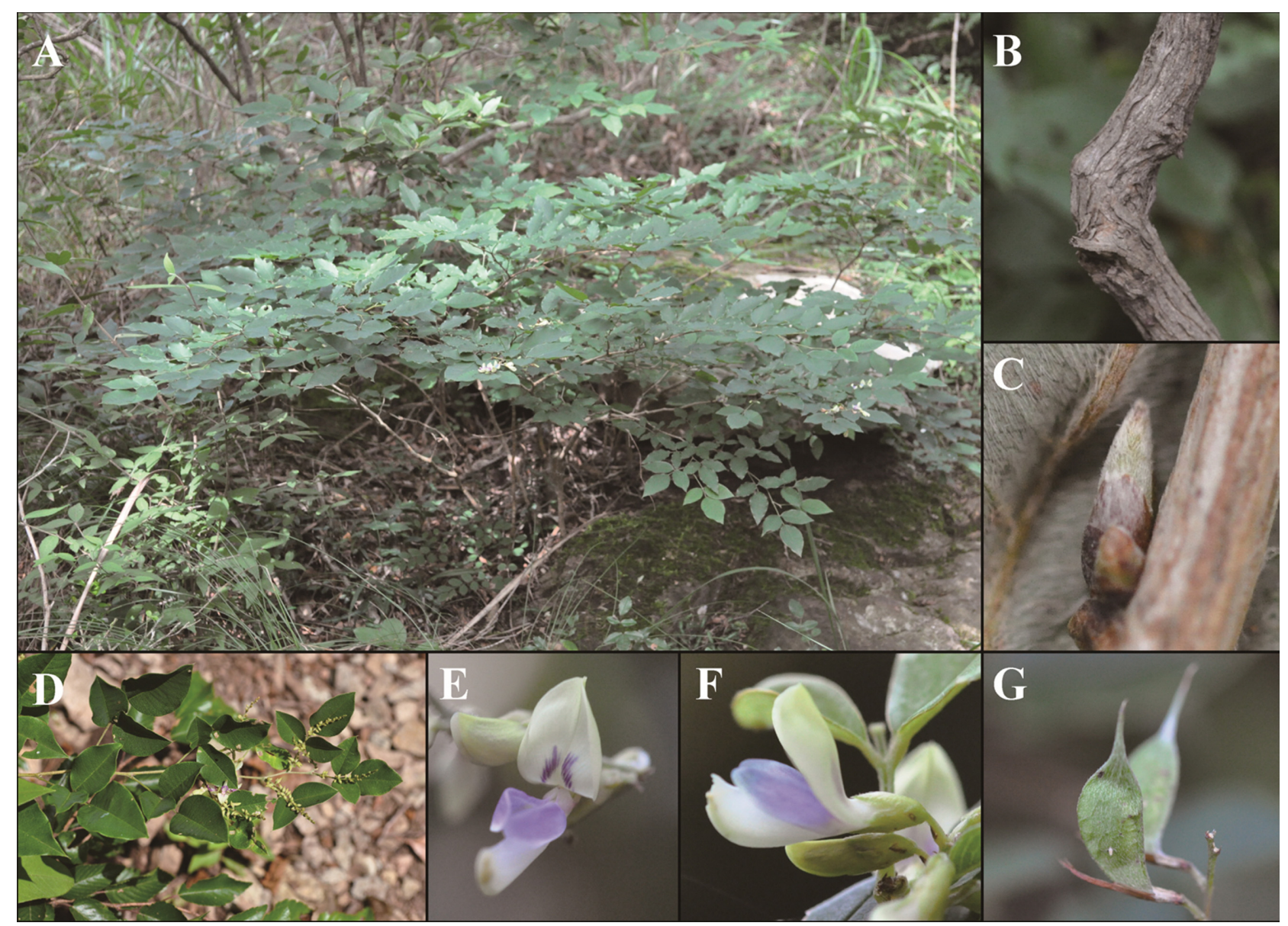

Fig. 7. Lespedeza tricolor (Nakai) D. P. Jin, J. W. Park \& B. H. Choi. A. Habit. B. Bark. C. Bud. D. Branch and leaves. E. Flower (front). F. Flower (side). G. Fruit.

$2.8 \mathrm{~mm}$ wide, pale yellow to white (similar or paler than standard petal); lamina 5.4-6.4 mm long, slightly falcate, obtuse at apex, sometimes purple dotted at apex; claw 2.2$2.9 \mathrm{~mm}$ long. Stamens 10, similar to keel petal in length, diadelphous $(9+1)$, white; filaments equal in length; anthers elliptic, retuse at both sides, ca. $0.4 \mathrm{~mm}$ long, ca. $0.2 \mathrm{~mm}$ wide, yellow. Pistil as long as stamen, with appressed hairs from base to middle, glabrous at apex; style elongated above anther; ovary narrow elliptic during flowering season, hairy. Legume slightly distorted elliptic, compressed, subsessile, ca. $13 \mathrm{~mm}$ long, ca. $5 \mathrm{~mm}$ wide, pilose, elongated spine-tip. Seed reniform, ca. $5 \mathrm{~mm}$ long, ca. $3 \mathrm{~mm}$ wide, glabrous.

Flowering: July-August.

Fruiting: September-October.

Distribution: Restricted to Korea (south-western regions of Jeollanam-do). Endemic.

Taxonomic note: This species resembles L. buergeri in color of flowers, order of petal length, shape of calyx, and glabrous upper surface of leaflets. However, the bracteole of each taxon is different. L. tricolor bears an ovate to elliptic form, whereas L. buergeri bears a round to elliptic form. In addition, bracteoles of $L$. buergeri could almost cover the calyx tube. Apex of leaflets of $L$. tricolor are generally acute to acuminate, but that of L. buergeri are usually obtuse to acute. Nakai (1923, 1927) and other researchers (Lee, 1965; Akiyama, 1988) mentioned that L. tricolor bears rosy keel petals, but our examination found that the color of keel petals was similar or paler than that of standard petal. On the other hand, $L$. maximowiczii has a purple standard petal, acute to acuminate leaflet apex, and elliptic bracteoles. Although L. maximowiczii is distinct from L. tricolor in the color of standard petal, the former is similar to the latter in shape of leaflets and bracteoles. Regarding genetic structure, L. tricolor harbors a mixed genetic lineage between L. buergeri and L. maximowiczii $(K=3)$ (Fig. $5)$, even L. tricolor shows an independent lineage from the latter two $(K=5)$ (Fig. 5). In a previous study (Jin et al., 
2016b), L. tricolor was originated from L. buergeri that had migrated from Japan, which experienced gene flow with $L$. maximowiczii in Korea during the Quaternary. Therefore, we considered $L$. tricolor as a distinct species from $L$. maximowiczii and L. buergeri.

Representative specimens examined: KOREA. Jeollanamdo: Jindo-gun, Galdu, 20 Jun 2002, J. O. Hyun \& H. K. Park 2002128-2002129 (KH); Jindo-gun, Seomang, 19 Jul 2006, $Y$. H. Cho et al. WR-060719-098 (KH); Jindo-gun, Cheomchalsan Mt., 11 Jul 2013, D. P. Jin 1307001-1307030 (IUI); Jindogun, Cheomchalsan Mt., 28 Sep 2008, E. S. Jeon ESJeon 81409 (KH); Jindo-gun, Temple Ssangyesa, 8 Aug 1964, T. Lee s.n. (SNUA); Haenam-gun, Dalmasan Mt., 8 Aug 2005, H. J. Choi CHJ 50159 (KH); Haenam-gun, Duryunsan Mt., 13 Aug 2003, E. S. Jeon ESJeon32119-1 (KH); Wando-gun, Sangwangbong Mt., 12 Jul 2013, D. P. Jin 1307031-1307042, 13070441307049, 1307051-1307053 (IUI); Wando-gun, Bogildo Isl., 22 Jul 2014, D. P. Jin \& I. S. Choi 1407127-1407131 (IUI); Wando-gun, Bogildo Isl., 22 Jul 2014, D. P. Jin \& I. S. Choi 1407127-1407131 (IUI); Wando-gun, Saengildo Isl., 23 Jul 2008, Y. H. Cho et al. WR-080723-239 (KH); Wando-gun, Daemodo Isl., 22 Jul 2010, S. C. Ko et al. HNHM-2010-0209 (KH); Gangjin-gun, Udubong peak, 25 Jul 2007, Y. H. Cho et al. WR-070725-222 (KH).

ORCID: Dong-Pil JIN https://orcid.org/0000-0002-3617-952X; Jong-Won PARK https://orcid.org/0000-0002-5877-4696; Byoung-Hee CHOI https://orcid.org/0000-0002-9234-9052

\section{Acknowledgments}

The authors are grateful to the persons concerned at the KH, SNUA, PE and TI herbaria for permitting the examination of specimens. We also thank our colleague J.S. Park, Plant Systematics Laboratory of Inha University, for commenting on this manuscript and editing the figures. This work was supported by the National Research Foundation of Korea (NRF) (No. NRF - 2018R1D1A1B07043030).

\section{Conflict of Interest}

The authors declare that there is no conflict of interest.

\section{Literature Cited}

Akiyama, S. 1988. A revision of the genus Lespedeza section Macrolespedeza (Leguminosae). The University Museum, The University of Tokyo, Bulletin 33: 1-170.
Akiyama, S. 2004. A new hybrid Lespedeza $\times$ miquelii (Leguminosae). Journal of Japanese Botany 79: 230-234.

Brunet, J., J. E. Zalapa, F. Pecori and A. Santini. 2013. Hybridization and introgression between the exotic Siberian elm, Ulmus pumila, and the native Field elm, U. minor, in Italy. Biological Invasions 15: 2717-2730.

Castillo-Mendoza, E., D. Salinas-Sánchez, L. Valencia-Cuevas, A. Zamilpa and E. Tovar-Sánchez. 2019. Natural hybridisation among Quercus glabrescens, Q. rugosa and Q. obtusata (Fagaceae): microsatellites and secondary metabolites markers. Plant Biology 21: 110-121.

Chang, C. S. and H. Kim. 2019. Flora of the Korean Peninsula. Version 1.16. TB Lee Herbarium. Occurrence dataset. Retrieved Nov. 12, 2019, available from https://doi.org/ 10.15468 /fyxnsd.

Choi, B. H. 2007. Lespedeza Michx. In The Genera of Vascular Plants of Korea. Park, C.-W. (ed.), Academy Publishing Co., Seoul. Pp. 614-618.

Duminil, J., D. Kenfack, V. Viscosi, L. Grumiau and O. J. Hardy. 2012. Testing species delimitation in sympatric species complexes: the case of an African tropical tree, Carapa spp. (Meliaceae). Molecular Phylogenetics and Evolution 62: 275-285.

Earl, D. A. and B. M. von Holdt. 2012. STRUCTURE HARVESTER: a website and program for visualizing STRUCTURE output and implementing the Evanno method. Conservation Genetics Resources 4: 359-361.

Hatusima, S. 1967. Lespedeza: sects. Macrolespedeza and Heterolespedeza from Japan, Corea and Formosa. Memoirs of the Faculty of Agriculture, Kagoshima University 6: 1-17.

Jin, D.-P., W.-B. Cho, I.-S. Choi and B.-H. Choi. 2016a. Isolation and characterization of 28 microsatellite loci for a Korean endemic, Lespedeza maritima (Fabaceae). Applications in Plant Sciences 4: 1500089.

Jin, D.-P., J.-H. Lee, B. Xu and B.-H. Choi. 2016b. Phylogeography of East Asian Lespedeza buergeri (Fabaceae) based on chloroplast and nuclear ribosomal DNA sequence variations. Journal of Plant Research 129: 793-805.

Jin, D.-P., B. Xu and B.-H. Choi. 2018. Taxonomic reconsideration of Chinese Lespedeza maximowiczii (Fabaceae) based on morphological and genetic features, and recommendation as an independent species L. pseudomaximowiczii. Korean Journal of Plant Taxonomy 48: 153-162.

Kopelman, N. M., J. Mayzel, M. Jakobsson, N. A. Rosenberg and I. Mayrose. 2015. CLUMPAK: a program for identifying clustering modes and packaging population structure inferences across K. Molecular Ecology Resources 15: 1179-1191.

Langella, O. 2011. Populations 1.2.32. Retrieved Dec. 9, 2019 available from http://www.bioinformatics.org/project/ 
?group_id=84.

Lee, J.-H., D.-P. Jin and B.-H. Choi. 2014. Genetic differentiation and introgression among Korean evergreen Quercus (Fagaceae) are revealed by microsatellite markers. Annales Botanici Fennici 51: 39-48.

Lee, M. H. 1978. Studies on the genus Lespedeza in Korea: characteristics chosen for an identification of the genus Lespedeza. Bulletin of the Arboretum Seoul National University 2: 7-28.

Lee, T. B. 1965. The Lespedeza of Korea (1). Bulletin of the Seoul National University Forests 2: 1-43.

Lee, T. B. 1980. Illustrated Flora of Korea. Hyangmunsa, Seoul. Pp. 468-472.

Lee, T. B. and M. H. Lee. 1975. The Lespedeza of Korea (2): trichomes for an identification of Lespedeza. Seoul National University Faculty Papers 4: 1-5.

Nakai, T. 1914. Vegetation of Island Wando (Wangto shokubutsu hokokusho). Governor-General of Korea (Chosen sotokufu). 35 pp. (in Japanese)

Nakai, T. 1919. Notulae ad plantas Japoniae et Coreae XXI. Botanical Magazine Tokyo 33: 193-216.

Nakai, T. 1923. Notulae ad plantas Japoniae et Coreae XXX. Botanical Magazine Tokyo 37: 69-82.

Nakai, T. 1927. Lespedeza of Japan and Korea. The Forestal Experiment Station of Government General of Chosen 6: 1101.

Nei, M., F. Tajima and Y. Tateno. 1983. Accuracy of estimated phylogenetic trees from molecular data. II. Gene frequency data. Journal of Molecular Evolution 19: 153-170.
Ohashi, H. and T. Nemoto. 2014. A new system of Lespedeza (Leguminosae tribe Desmodieae). Journal of Japanese Botany 89: 1-11.

Ohashi, H., T. Nemoto and K. Ohashi. 2009. A revision of Lespedeza subgenus Macrolespedeza (Leguminosae) in China. Journal of Japanese Botany 84: 197-223.

Pritchard, J. K., M. Stephens and P. Donnelly. 2000. Inference of population structure using multilocus genotype data. Genetics 155: 945-959.

Schindler, A. K. 1911. Lespedezae novae et criticae. I. Repertorium novarum specierum regni vegetabilis 9: 514-523. (in German)

Uyeki, H. 1941. Trees and forests (Jumoku to shinrin). Bulletin of Forestry Society of Korea (Chosen sanrin kaiho) 194: 7-13. (in Japanese)

Xu, B., N. Wu, X.-F. Gao and L.-B. Zhang. 2012. Analysis of DNA sequences of six chloroplast and nuclear genes suggests incongruence, introgression, and incomplete lineage sorting in the evolution of Lespedeza (Fabaceae). Molecular Phylogenetics and Evolution 62: 346-358.

Xu, B., X.-M. Zeng, X.-F. Gao, D.-P. Jin and L.-B. Zhang. 2017. ITS non-concerted evolution and rampant hybridization in the legume genus Lespedeza (Fabaceae). Scientific Reports 7: 40057.

Zeng, Y.-F., J.-G. Zhang, A.-G. Duan and B. Abuduhamiti. 2016. Genetic structure of Populus hybrid zone along the Irtysh River provides insight into plastid-nuclear incompatibility. Scientific Reports 6: 28043. 


\section{조록싸리 종내분류군과 잡종의 분류학적 연구 \\ 진동필 · 박종원 · 최병희* \\ 인하대학교 생명과학과}

적 요: 조록싸리(Lespedeza maximowiczii) 내에 많은 종내분류군들 및 근연분류군과의 잡종들이 기록되었지 만, 이들의 분류학적 실체에 대해서는 학자들간에 이견이 있다. 본 연구는 조록싸리와 근연분류군간 잡종인 지리산싸리(L. chiisanensis), 진도싸리(L. patentibicolor) 및 조록싸리의 종내분류군인 털조록싸리(var. tomentella), 늦싸리(var. elongata), 삼색싸리(var. tricolor)의 실체를 규명하기 위해, 외부형태를 관찰하고 microsatellite를 이용하여 유전적 구조를 분석하였다. 연구 결과 털조록싸리와 늦싸리의 꽃과 잎의 형태는 조 록싸리의 변이폭에 속했고, 유전적으로도 두 분류군이 조록싸리와 같이 묶였다. 삼색싸리는 꽃의 구조와 색 에서 근연종인 L. buergeri와 유사한 반면 소엽 정단부와 소포엽의 형태는 조록싸리와 가까웠다. 유전적 구조 에서도 삼색싸리의 개체들은 조록싸리와 L. buergeri의 계통이 혼합된 형태를 보이거나 $(K=3)$, 독립되었다 $(K=5)$. 잡종들의 경우, 지리산싸리의 꽃과 잎의 형태는 조록싸리와 구별되지 않는 반면, 진도싸리의 꽃 형질 은 싸리(L. bicolor)의 변이폭에 속했는데, 유전적 계통도 각각 조록싸리와 싸리로 지정되었다. 본 연구결과를 종합하여 저자들은 털조록싸리와 늦싸리를 조록싸리의 품종, f. friebeana (Schindl.) D. P. Jin, J. W. Park \& B. H. Choi로 처리하였는데, 이는 L. friebeana가 var. tomentella 보다 먼저 발표되었기 때문이다. 또한 삼색싸 리는 독립종, L. tricolor (Nakai) D. P. Jin, J. W. Park \& B. H. Choi 로 처리하였고, 지리산싸리는 조록싸리의 이명으로 처리하였다. 한편 진도싸리는 싸리의 이명으로 판단된다.

주요어: 잡종, 종내분류군, 조록싸리, 형태 변이, microsatellite, 분류학적 처리 